WATER BUDGET AND MATHEMATICAL MODEL

OF THE COCONIMO AQUIFER, SOUTHERN NAVAJO COUNTY, ARIZONA

By Larry J. Mann

U.S. Geological Survey Open-File Report 79-348

January 1979 


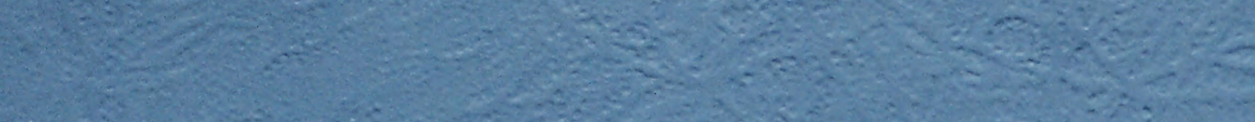

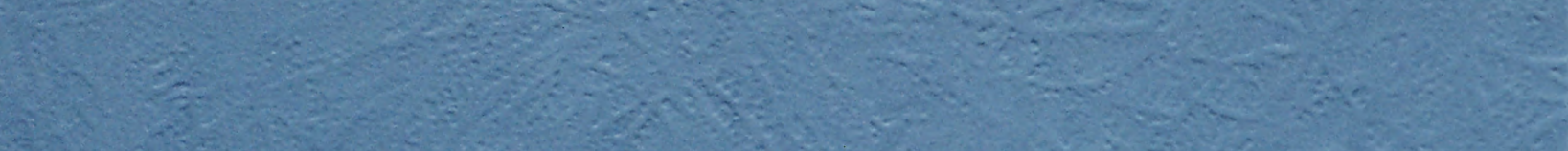

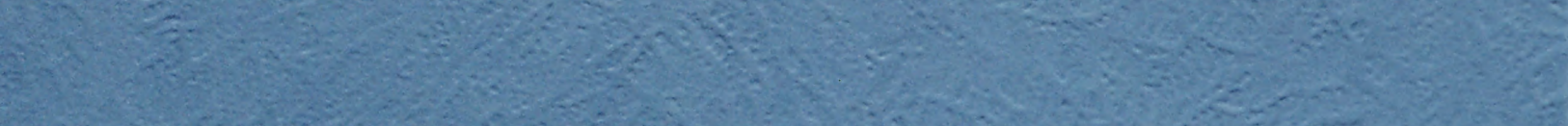
(1)

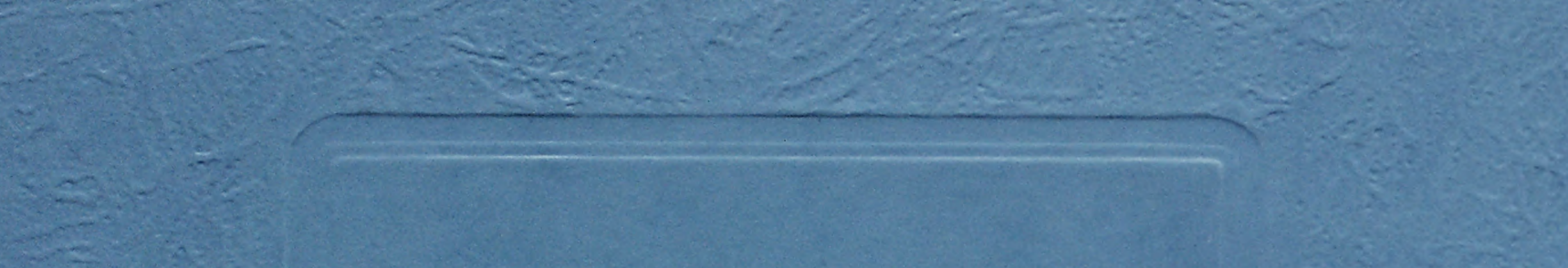

x.

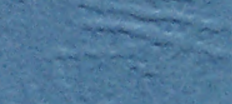

10

-
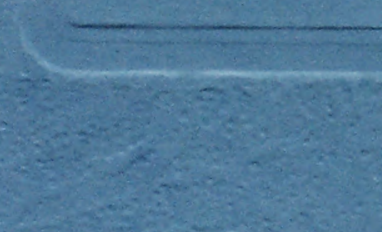

$$
\begin{aligned}
& - \\
& x^{2}
\end{aligned}
$$$$
x^{2}
$$

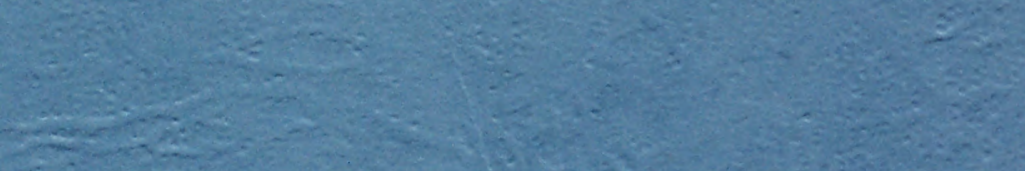

rise

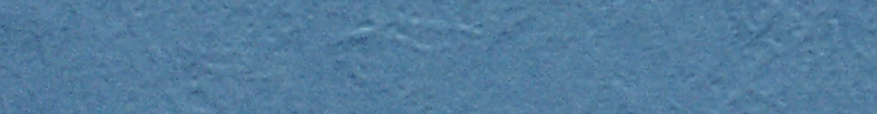

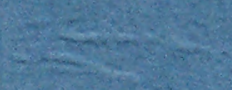


(200)

$R 290$

no. $79-348$

$$
\begin{aligned}
& \checkmark \\
& \begin{array}{c}
\text { UNITED STATES . } \\
\text { (DEPARTMENT OF THE INTERIOR) } \\
\text { GEOLOGICAL SURVEY }
\end{array} \\
& \text { 3 } 1818000729549 \\
& \text { GEOLOGICAL SURVEY. } \\
& \text { EReports-open file series }]
\end{aligned}
$$

WATER BUDGET AND MATHEMATICAL MODEL

OF THE COCONINO AQUIFER, SOUTHERN

noTM

NAVAJO COUNTY, ARIZONA

VTwanal

Open-File Report 79-348

Prepared in cooperation with the Arizona Water Commission

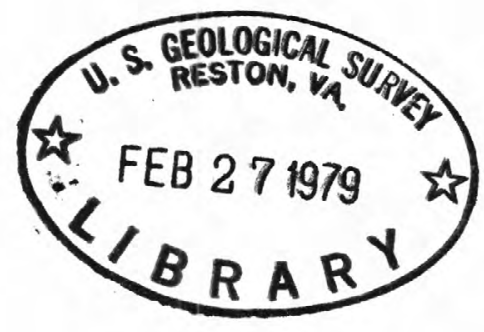



UNITED STATES

DEPARTMENT OF THE INTERIOR

GEOLOGICAL SURVEY

WATER BUDGET AND MATHEMATICAL MODEL

OF THE COCONINO AQUIFER, SOUTHERN

NAVAJO COUNTY, ARIZONA

By Larry J. Mann $s$

Open-File Report 79-348

$\checkmark G S$

Prepared in cooperation with the Arizona.Water Commission.

Tucson, Arizona

January 1979 



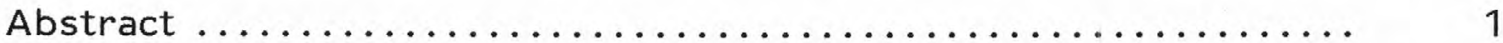

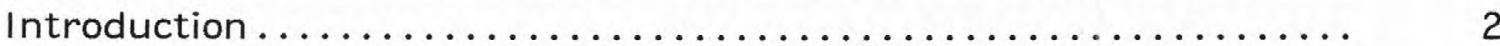

Purpose of the investigation and scope

of the report............................ 4

Relation of the investigation to previous

studies.................................. 4

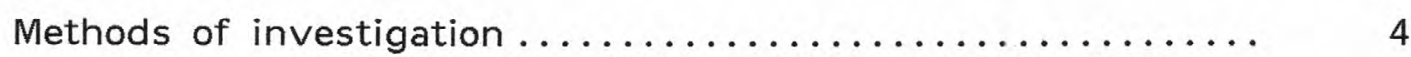

Geohydrologic setting ............................. 6

Hydraulic characteristics of the Coconino aquifer ............. 11

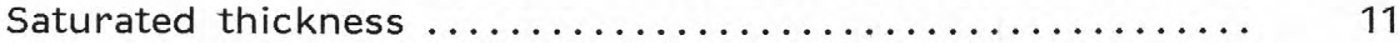

Hydraulic conductivity ....................... 12

Storage coefficient $\ldots \ldots \ldots \ldots \ldots \ldots \ldots \ldots \ldots \ldots \ldots \ldots \ldots \ldots \ldots \ldots \ldots$

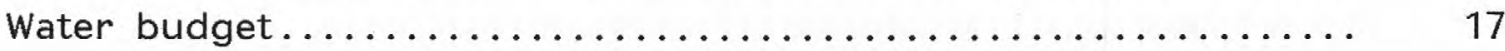

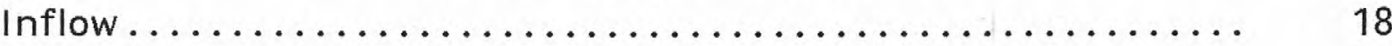

Infiltration of precipitation and streamflow ........................... 18

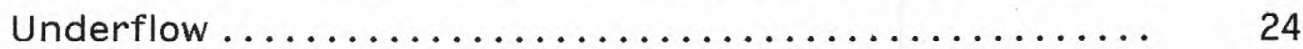

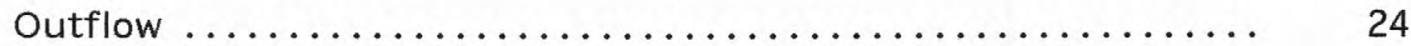

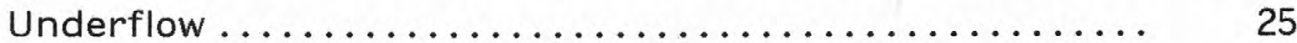

Streamflow and springs..................... 25

Evapotranspiration ..................... 28

Ground-water withdrawals .................. 29

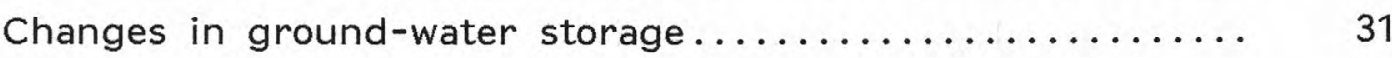



Steady-state simulation $\ldots \ldots \ldots \ldots \ldots \ldots \ldots \ldots \ldots \ldots \ldots \ldots \ldots \ldots \ldots \ldots$

Transient simulation ............................ 39

Limitations and use of the model ................. 48

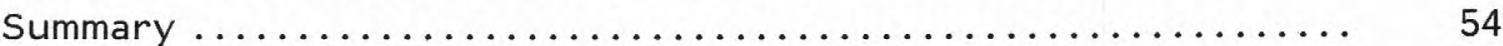

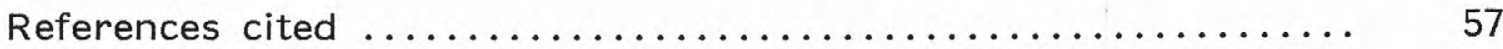




\section{ILLUSTRATIONS}

Page

Figure 1. Map showing area of report and Arizona's water provinces $\ldots \ldots \ldots \ldots \ldots \ldots \ldots \ldots \ldots \ldots \ldots \ldots \ldots \ldots \ldots$

2. Map showing geohydrology of the Coconino

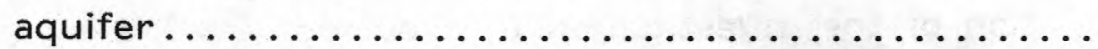

3. Map showing saturated thickness of the Coconino aquifer

4. Map showing estimated inflow to and outflow from the Coconino aquifer under assumed equilibrium conditions in 1960 as determined from the flow-net analysis and field data $\ldots \ldots \ldots \ldots \ldots \ldots$

5. Graph showing estimated ground-water pumpage from the Coconino aquifer, $1960-72 \ldots \ldots \ldots \ldots \ldots \ldots$

6. Map showing distribution of the hydraulic conductivity and the nodal array used in the steady-state

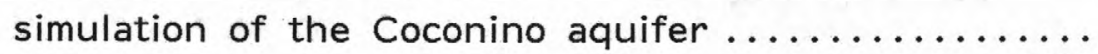

7. Map showing measured and simulated water-level altitudes in the Coconino aquifer under assumed equilibrium conditions in $1960 \ldots \ldots \ldots \ldots \ldots \ldots$

8. Map showing distribution of storage coefficients and pumpage by township used in the 1960-72

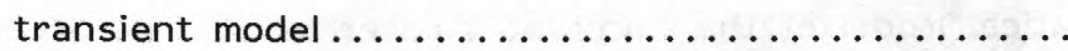

9. Graphs showing measured and simulated water-level changes in selected wells, $1960-73 \ldots \ldots \ldots \ldots \ldots \ldots$

10. Map showing measured and simulated water-level declines near Snowflake, Taylor, and Shumway .....

11. Map showing simulated water-level declines in the Coconino aquifer, $1960-72 \ldots \ldots \ldots \ldots \ldots \ldots \ldots$ 
TABLES

Page

Table 1. Results of flow-net analysis for area south

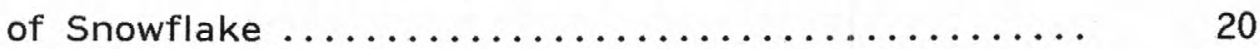

2. Discharge measurements of base flow at

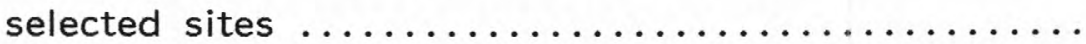

3. Water budget used in steady-state

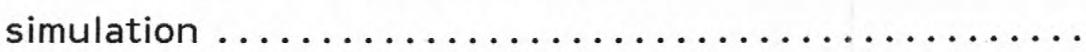

4. Average annual water budget for the transient simulation, $1960-72 \ldots \ldots \ldots \ldots \ldots \ldots \ldots$ 


\section{CONVERSION FACTORS}

For use of those readers who may prefer to use metric units rather than inch-pound units, the conversion factors for the terms used in this report are listed below:

\begin{tabular}{|c|c|c|}
\hline Multiply inch-pound unit & By & To obtain metric unit \\
\hline inch (in.) & 25.4 & millimeter $(\mathrm{mm})$ \\
\hline foot $(\mathrm{ft})$ & 0.3048 & meter $(\mathrm{m})$ \\
\hline mile $(\mathrm{mi})$ & 1.609 & kilometer $(\mathrm{km})$ \\
\hline acre & 0.004047 & square kilometer $\left(\mathrm{km}^{2}\right)$ \\
\hline square mile $\left(\mathrm{mi}^{2}\right)$ & 2.590 & square kilometer $\left(\mathrm{km}^{2}\right)$ \\
\hline acre-foot (acre-ft) & 0.001233 & cubic hectometer $\left(\mathrm{hm}^{3}\right)$ \\
\hline acre-foot per acre & & cubic hectometer per \\
\hline (acre-ft/acre) & 0.3047 & square kilometer $\left(\mathrm{hm}^{3} / \mathrm{km}^{2}\right)$ \\
\hline acre-foot per mile & & cubic hectometer per \\
\hline (acre-ft/mi) & 0.0007663 & kilometer $\left(\mathrm{hm}^{3} / \mathrm{km}\right)$ \\
\hline $\begin{array}{l}\text { acre-foot per square } \\
\text { mile }(\text { acre-ft/mi²) }\end{array}$ & 0.0004760 & $\begin{array}{l}\text { cubic hectometer per square } \\
\text { kilometer }\left(\mathrm{hm}^{3} / \mathrm{km}^{2}\right)\end{array}$ \\
\hline foot squared $\left(\mathrm{ft}^{2}\right)$ & 0.0929 & meter squared $\left(\mathrm{m}^{2}\right)$ \\
\hline $\begin{array}{l}\text { cubic foot per second } \\
\left(\mathrm{ft}^{3} / \mathrm{s}\right)\end{array}$ & 0.02832 & $\begin{array}{l}\text { cubic meter per second } \\
\qquad\left(m^{3} / \mathrm{s}\right)\end{array}$ \\
\hline $\begin{array}{l}\text { gallon per minute } \\
\qquad(\mathrm{gal} / \mathrm{min})\end{array}$ & 0.06309 & $\begin{array}{l}\text { liter per second } \\
(L / s)\end{array}$ \\
\hline
\end{tabular}




\title{
WATER BUDGET AND MATHEMATICAL MODEL \\ OF THE COCONINO AQUIFER, SOUTHERN \\ NAVAJO COUNTY, ARIZONA
}

By

Larry J. Mann

\begin{abstract}
The main source of water in the 3,400-square-mile area of southern Navajo County is the large volume of ground water in storage in the Coconino aquifer, which consists of the Coconino Sandstone, the uppermost part of the underlying Supai Formation, and the overlying Kaibab Limestone. The amount of water withdrawn from the aquifer increased from about 13,800 acre-feet in 1960 to 38,400 acre-feet in 1972. As industrial and agricultural development continues, the amount of withdrawal probably will increase greatly.

Aquifer tests indicate that the hydraulic conductivity of the aquifer ranges from 8 to 40 feet per day; however, a flow-net analysis indicates that the hydraulic conductivity may be as much as 80 feet per day in the north-central part of the area. In the southern and central parts of the area the aquifer is unconfined, and the storage coefficient is estimated to be about 0.15. In the northern and eastern parts the aquifer is confined, and the storage coefficient ranges from 0.00013 to 0.0014 .
\end{abstract}

A mathematical model was developed to simulate the groundwater system and to provide a management tool for estimating the effects of present and future ground-water withdrawals. The model indicates that the inflow to and outflow from the aquifer were about 105,600 acre-feet in 1960 prior to extensive ground-water development and that about 192,000 acre-feet of water was derived from groundwater storage between 1960 and 1972. The mathematical model provides an approximation of the Coconino aquifer and can be used to estimate the future response of the aquifer. 


\section{INTRODUCTION}

Southern Navajo County occupies about $3,400 \mathrm{mi}^{2}$ in northeastern Arizona (fig. 1). The study area is bounded on the north by the Navajo Indian Reservation; the county lines are the east and west boundaries. For the purpose of this study, the south boundary of the modeled area was established along the ground-water divide that nearly parallels the boundary of the Fort Apache Indian Reservation. The area is mainly in the Plateau uplands water province; however, a small part along the south boundary is in the Central highlands water province (fig. 1).

The water supply for southern Navajo County is derived mainly from the Coconino aquifer, which underlies the entire area. In 1972 slightly more than 75 percent of the water that was consumptively used was obtained from the Coconino aquifer. Of the 38,400 acre-ft of water withdrawn from the aquifer in 1972, about 60 percent was for irrigation; 35 percent for industry; and 5 percent for municipal, domestic, and livestock supplies. The main agricultural areas are near Shumway, Taylor, Snowflake, Hay Hollow, Holbrook, and Joseph City (fig. 1), where the aquifer yields large quantities of water from relatively shallow depths. The two main water-using industrial complexes are near Joseph City and Snowflake. As a result of the ground-water withdrawals near Shumway, Taylor, and Snowflake, water levels declined as much as $50 \mathrm{ft}$ from spring 1951 to spring 1973. Near the other pumping centers, water levels declined less than $20 \mathrm{ft}$ and generally less than $5 \mathrm{ft}$.

As industrial and agricultural development continues, the amount of ground water withdrawn probably will increase greatly. This study was undertaken by the U.S. Geological Survey in cooperation with the Arizona Water Commission to evaluate the possible effects of present and future ground-water withdrawals on the Coconino aquifer. 


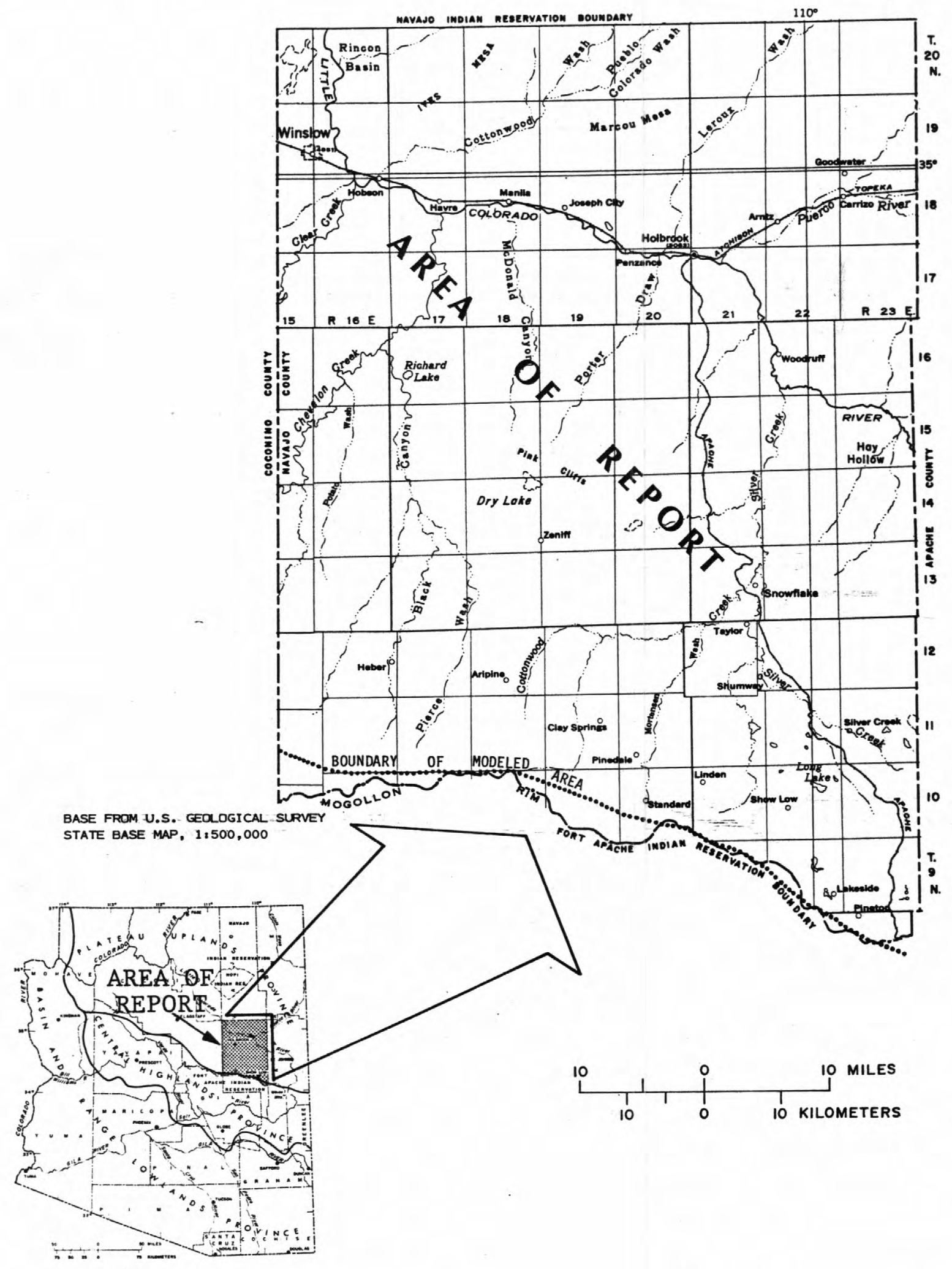

Figure 1.--Area of report and Arizona's water provinces. 


\section{Purpose of the Investigation and Scope of the Report}

The purpose of the investigation was to determine the hydraulic characteristics and water budget for the Coconino aquifer in southern Navajo County and to develop a mathematical model as a management tool for estimating the effects of present and future ground-water withdrawals. The report describes (1) the hydraulic characteristics of the Coconino aquifer based on the available data and the effects of geologic controls on ground-water movement and storage; (2) a tentative water budget for the aquifer and the general areas, sources, and magnitude of inflow and outflow; and (3) the development of a mathematical model of the aquifer and the evaluation and modification of input data to simulate the ground-water system.

\section{Relation of the Investigation to Previous Studies}

A general appraisal of the ground-water conditions in southern Navajo County (Mann, 1976) pointed out the need for additional analysis of and data for the Coconino aquifer. Most of the data collected during the appraisal study and data collected during this study that define the hydraulic characteristics, inflow to, and outflow from the aquifer are used in the water budget and in the mathematical model. Data from other studies were used to define the long-term trends in ground-water withdrawals and water-level declines. Geohydrologic data from Harrell and Eckel (1939) were used in the Holbrook region. Similar data from Babcock and Snyder (1947) and Babcock (1948) were used in the Joseph City area, and data from Johnson (1962) were used in the Snowflake and Hay Hollow areas. Subsurface geologic data were obtained from Scurlock (1971) and Peirce and Scurlock (1972).

\section{Methods of Investigation}

Data collected as part of this study include water-level measurements in selected wells, aquifer tests in selected wells that 
penetrate the Coconino aquifer, and streamflow measurements along the Little Colorado River and its tributaries. These data are used in conjunction with data collected during previous studies. An analysis of the streamflow data for Chevelon Creek was made to estimate the amount of infiltration.

A flow-net analysis using the approximate potentiometric surface in 1960 (fig. 2) and the saturated thickness of the aquifer (fig. 3) was developed to estimate the water-budget parameters and the upper and lower limits of hydraulic conductivity. Water-level measurements made prior to 1960 were used to develop the flow net in areas where water levels had declined only slightly owing to pumping. Prior to 1960, the magnitude of ground-water withdrawal and the areal extent of water-level declines were small. The flow-net analysis was used to calculate inflow to the aquifer in areas where the hydraulic conductivity was defined by field data. After the inflow for a specific area was determined, it was extrapolated over a large area, and the flow-net analysis was used to estimate hydraulic conductivity in the parts of the area where no field data were available. Most of the geohydrologic parameters were unknown; therefore, the determination of the water-budget parameters by flow-net analysis was a trial-and-error procedure.

A mathematical model was developed to simulate the flow of ground water in the Coconino aquifer-a practical way to evaluate the response of the system to natural and manmade stresses. In the model the differential equation for two-dimensional nonsteady-state flow of a homogeneous compressible fluid in an elastic nonhomogeneous aquifer was approximated by a finite-difference equation as described by Pinder (1970). Data used in the development of the model include saturated thickness, hydraulic conductivity, storage coefficient, inflow and outflow values, and periodic water-level measurements. 


\section{GEOHYDROLOGIC SETTING}

Southern Navajo County is in the high plateau country of northeastern Arizona. The plateau country consists of flatlands and rolling hills cut by steep-walled canyons and broad valleys. The most prominent topographic features are the Mogollon Rim near the south boundary and the foothills of the White Mountains in the southeastern part of the area. The Mogollon Rim escarpment is well defined and has a maximum relief of about $2,000 \mathrm{ft}$.

Altitudes range from about 6,800 to $7,650 \mathrm{ft}$ above mean sea level near the Mogollon Rim in the southern part of the area and from about 5,000 to $5,500 \mathrm{ft}$ along the Little Colorado and Puerco Rivers in the northern part of the area. In the southern and central parts of the area the general slope of the land surface is northward from the mountains toward the Little Colorado River. In the northern part, however, the slope is southward toward the Little Colorado and Puerco Rivers. The normal annual precipitation ranges from about 8 in. in the northern part of the area to as much as 30 in. near the Mogollon Rim (University of Arizona, 1965a, 1965b). In the southern part of the area about half the annual precipitation falls as snow in the winter.

The Little Colorado River, which is the main stream that drains the area, flows generally northwestward from its headwaters in the White Mountains to its junction with the Puerco River and eventually joins the Colorado River in northern Arizona (fig. 1). The major tributaries to the Little Colorado River are Silver, Chevelon, and Clear Creeks on the south and southwest and the Puerco River and Leroux and Cottonwood Washes on the northeast (fig. 1). Although most streams in the area are ephemeral, Silver Creek, the lower reaches of Chevelon and Clear Creeks, and some reaches of the Little Colorado River are perennial.

Southern Navajo County is underlain by a bedded sequence of sedimentary rocks that are overlain in places by basaltic rocks and 
alluvial deposits. The uppermost part of the Supai Formation of Permian age is the lowermost unit tapped by wells. Sedimentary rocks that overlie the Supai Formation include, in ascending order, the Coconino Sandstone and Kaibab Limestone of Permian age, the Moenkopi and Chinle Formations of Triassic age, and a sequence of Upper Cretaceous sedimentary rocks (Mann, 1976, pl. 1). The Coconino Sandstone is the oldest formation exposed in the area, although the Supai crops out along the Mogollon Rim escarpment a few miles south of the area.

The most striking structural characteristic of the sedimentary rocks is their broad gentle northward dip, which is modified in places by folds. The most prominent fold is the Holbrook anticline, which trends west-northwest across the central part of the area (fig. 2). Near Zeniff, the sedimentary rocks have been uplifted as much as $400 \mathrm{ft}$ by the anticline (Mann, 1976, pl. 2). The anticline is paralleled along its southwest limb by the Dry Lake syncline, which has a maximum closure of about $250 \mathrm{ft}$ near Snowflake and Taylor. Many sinkholes are present along the anticline and syncline.

The main source of water in southern Navajo County is the large volume of ground water in storage in the Coconino aquifer, which underlies the entire area. The Coconino aquifer is the most productive aquifer and is the deepest source of water that has been developed in the area. The aquifer is composed of the Coconino Sandstone, the uppermost part of the underlying Supai Formation, and the overlying Kaibab Limestone. The regional dip of the sedimentary units that form the aquifer and the general direction of ground-water movement are northward from the Mogollon Rim toward the Little Colorado River (fig. 2).

The Supai Formation underlies the entire area, and the uppermost part consists of siltstone, sandstone, halite, gypsum, and anhydrite beds. The uppermost part ranges in thickness from 450 to $1,300 \mathrm{ft}$ and thickens toward the north-central part of the area near 


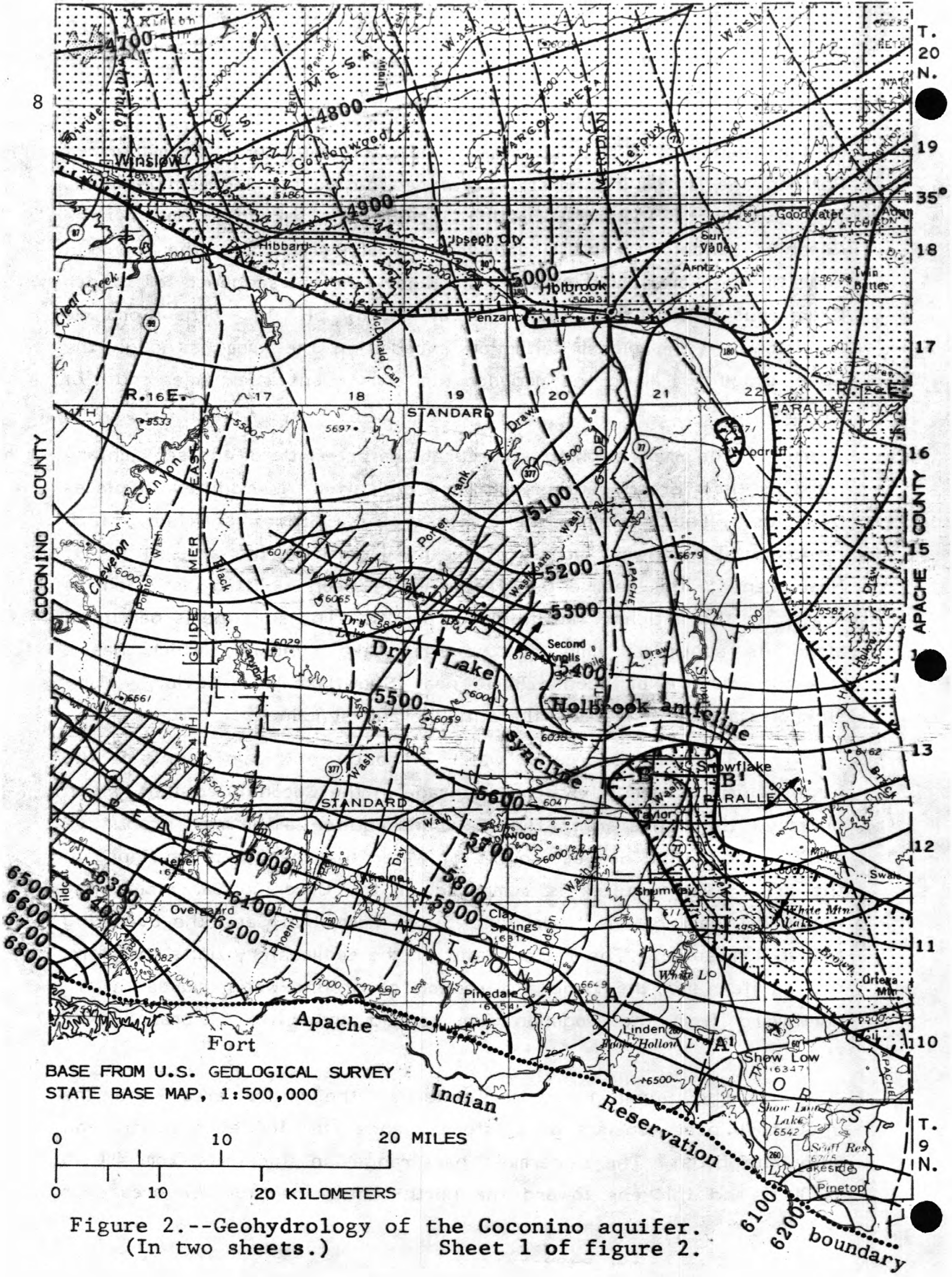




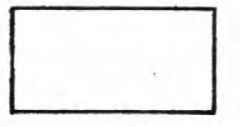

AREA WHERE THE COCONINO AQUIFER IS PARTLY SATURATED

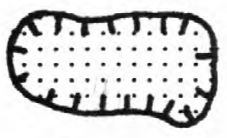

AREA WHERE WATER IN THE COCONINO AQUIFER IS CONFINED

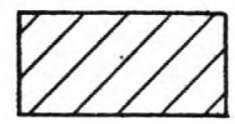

APPROXIMATE AREA WHERE THE UPPER UNITS OF THE COCONINO AQUIFER ARE ABOVE THE WATER TABLE-Water is obtained from wells that tap the uppermost part of the Supai Formation

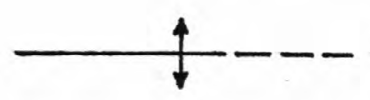

ANTICLINE-Showing trace of crestal plane; dashed where approximately located

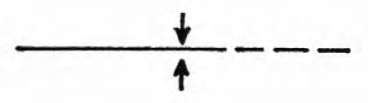

SYNCLINE_Showing trace of trough plane; dashed where approximately located

GROUND-WATER DIVIDE-Shows approximate location. Forms south boundary of modeled area

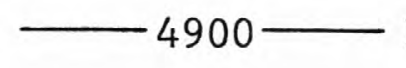

POTENTIOMETRIC CONTOUR-Shows approximate altitude at which water level would have stood in tightly cased wells, 1960. Contour interval 100 feet. Datum is mean sea level

GENERALIZED FLOW LINE-Convergence of flow lines indicates that much of the underflow probably is discharged to Chevelon and Silver Creeks

A- $A^{\prime}$ LOCATION OF SAMPLE CROSS SECTION USED TO COMPUTE HYDRAULIC CONDUCTIVITY

Figure 2.--Geohydrology of the Coconino aquifer. (In two sheets.) Sheet 2 of figure 2 . 
Holbrook. The sandstone beds in the upper 0 to $200 \mathrm{ft}$ of this unit are in hydraulic connection with the overlying Coconino Sandstone. The siltstone, halite, gypsum, and anhydrite beds are nearly impermeable and probably impede the downward movement of water into the underlying strata (Mann, 1976, pl. 1). Along the crest of the Holbrook anticline, however, the siltstone beds are in hydraulic connection with the Coconino Sandstone where the siltstone has been fractured owing to structural deformation and solution collapse of the halite, gypsum, and anhydrite beds by moving ground water.

The Coconino Sandstone is the main water-bearing unit of the Coconino aquifer, underlies the entire area, and generally yields from 500 to $2,000 \mathrm{gal} / \mathrm{min}$ of water to wells. The Coconino Sandstone ranges in thickness from about $250 \mathrm{ft}$ near Show Low to $850 \mathrm{ft}$ near Winslow and is partly to completely saturated in most of the area. Along the crest of the Holbrook anticline and in a $40-\mathrm{mi}^{2}$ area northwest of Heber, however, the Coconino Sandstone is above the potentiometric surface and is drained of water (fig. 2). In these areas the wells that tap the Coconino aquifer obtain their water from the sandstone and fractured siltstone beds in the uppermost part of the Supai Formation.

The Kaibab Limestone is present in the southern and central parts of the area and contains sandstone beds that are lithologically similar to those of the Coconino Sandstone. The Kaibab ranges in thickness from 0 to about $200 \mathrm{ft}$ and is not saturated in most of the area. The Kaibab is highly permeable and allows rapid infiltration of water into underlying units.

The Moenkopi Formation is composed of nearly impermeable siltstone and mudstone and 30 - to $50-\mathrm{ft}$-thick sandstone beds near the top and base. In places the sandstone beds yield water to wells. In some places in the southern and central parts of the area the Moenkopi directly overlies the Kaibab Limestone, and in the northern part the Moenkopi directly overlies the Coconino Sandstone. The Moenkopi Formation acts as a confining bed where the underlying Coconino 
aquifer is completely saturated. Water confined in the Coconino aquifer by the Moenkopi is under sufficient pressure to rise as much as $500 \mathrm{ft}$ above the top of the aquifer in some places.

The quantity of ground water in storage in the Coconino aquifer in southern Navajo County is much larger than the sum of the parts of the annual water budget for the aquifer. The volume of ground water in storage is the product of the volume of the aquifer and the estimated specific yield. On the basis of an estimated specific yield of 0.15 (see section entitled "Storage Coefficient"), about 140 million acre-ft of ground water is stored in the aquifer. In contrast, the quantity of water withdrawn from the aquifer by wells prior to 1973 probably was less than 600,000 acre-ft or 0.4 percent of the ground water in storage.

\section{HYDRAULIC CHARACTERISTICS OF THE COCONINO AQUIFER}

The hydraulic characteristics of the Coconino aquifer control the downgradient movement of ground water from areas of inflow to areas of outflow, the potential rate of ground-water withdrawal, and the magnitude and areal distribution of water-level declines. The hydraulic characteristics-saturated thickness, hydraulic conductivity, and storage coefficient - of the Coconino aquifer were determined mainly from drill-hole and aquifer-test data. A flow-net analysis aided in the estimation of hydraulic conductivity where field data were not available.

\section{Saturated Thickness}

The saturated thickness of the Coconino aquifer is not well defined in most of the area because water wells generally do not penetrate the entire thickness of the aquifer. The saturated thickness can be inferred only from data from the few scattered oil-, gas-, mineral-, and water-test holes. In general, the saturated thickness of the aquifer includes only the thickness of the saturated sandstone and 
limestone beds. The sandstone beds in the Coconino Sandstone and in the uppermost part of the Supai Formation generally contain water. Along the crest of the Holbrook anticline, however, the sandstone beds are above the water table, and wells that tap the aquifer obtain their water from the fractured siltstone beds in the Supai. The siltstone beds probably are not fractured in the rest of the area and are assumed to be impervious.

The saturated thickness of the Coconino aquifer ranges from about $150 \mathrm{ft}$ near the Mogollon $\operatorname{Rim}$ to $850 \mathrm{ft}$ near Winslow (fig. 3). Where the sandstone and limestone beds are above the water table, the saturated thickness of the aquifer is assumed to be about $350 \mathrm{ft}$; therefore, as much as $350 \mathrm{ft}$ of fractured siltstone, halite, gypsum, and anhydrite are included in the aquifer near the Holbrook anticline.

\section{Hydraulic Conductivity}

The hydraulic conductivity of the Coconino aquifer varies vertically and laterally throughout the area. The lithologic characteristics and the degree of fracturing of the aquifer are the main factors that affect the hydraulic conductivity. The vertical and lateral changes in hydraulic conductivity result largely from changes in grain size, degree of cementation of the water-bearing material, or both. The hydraulic conductivity, therefore, is greater in places where the water-bearing material is composed of moderately to poorly cemented sandstone and smaller where the water-bearing material is composed of well-cemented sandstone or silty sandstone.

Fracturing owing to structural deformation and solution collapse greatly influences the occurrence, movement, and yield of water in the Coconino aquifer. Extensive parting of bedding planes, which are well developed in outcrops of the Coconino Sandstone, increases the hydraulic conductivity. Where the aquifer material is fractured, the movement of ground water is not limited to the 
interstices of the saturated rock, and the water moves with less resistance along interconnected fractures. Wells that tap a fractured zone generally reflect much greater values of hydraulic conductivity than wells that tap an unfractured zone.

Aquifer-test and specific-capacity data and a flow-net analysis were used to estimate the hydraulic conductivity of the Coconino aquifer. Where aquifer-test data were available, hydraulic-conductivity values were calculated from transmissivity and saturated-thickness data. Where no aquifer-test data were available, transmissivity values were estimated on the basis of specific-capacity data. Estimates of transmissivity were obtained by multiplying the specific-capacity values by 270 (Theis and others, 1963). Transmissivity values obtained using specific-capacity data are, at best, estimates. The specific capacity of a well depends not only on the transmissivity of the aquifer but on other factors, such as the extent of aquifer penetration by the well, type of casing perforations, well diameter, and completeness of well development. A generalized flow net was developed to estimate hydraulic-conductivity values where aquifer-test and specific-capacity data were not available (fig. 2).

Underflow was computed at selected cross sections where the hydraulic conductivity was determined from aquifer-test data by the equation

$$
Q=K \mid A,
$$

where

$Q=$ underflow, in cubic feet per day;

$\mathrm{K}=$ hydraulic conductivity, in feet per day;

$\mathrm{I}=$ hydraulic gradient, in foot per foot; and

$A=$ area through which underflow occurs, in square feet. A is equal to the product of the saturated thickness, in feet, and the distance between flow lines, in feet. 
NAYAJO INDIAN RESERVATION BOUNDARY

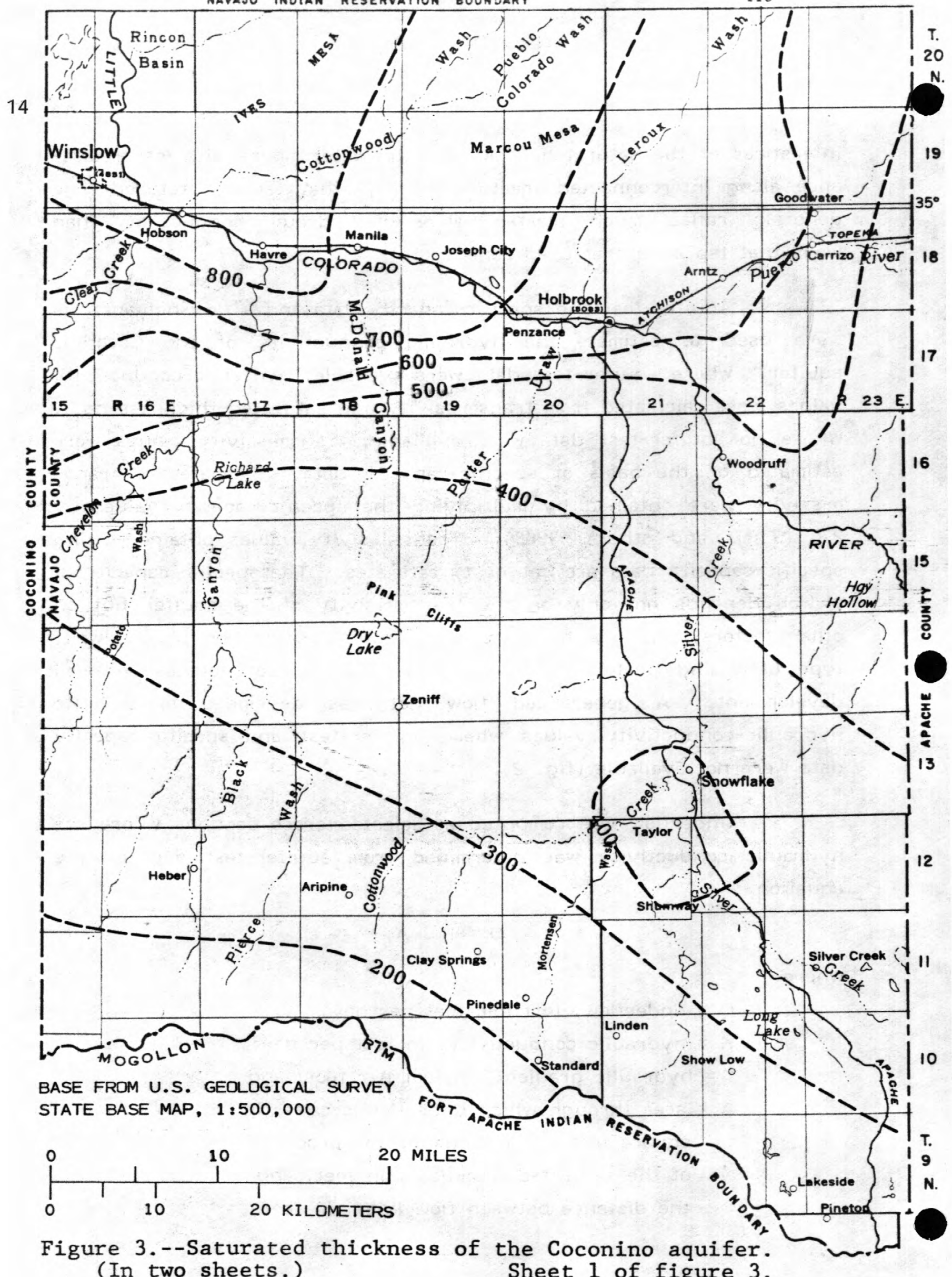

(In two sheets.)

Sheet 1 of figure 3 . 


\section{- - 800 - APPROXIMATE LINE OF EQUAL SATURATED THICKNESS \\ OF THE COCONINO AQUIFER, 1960-Interval \\ 100 feet}

Figure 3.--Saturated thickness of the Coconino aquifer. (In two sheets.) Sheet 2 of figure 3. 
Underflow computed by eq 1 was used to obtain preliminary estimates of hydraulic conductivity at additional cross sections delineated by the same pair of flow lines. Underflow between two consecutive cross sections was adjusted for any significant inflow or outflow in the intervening reach. The adjusted underflow value and values for $I$ and $A$ at the second cross section were used to solve $K$ in eq 1. In many places the flow net could not be used to estimate $K$ because of large differences in the amounts of inflow and outflow between cross sections and insufficient water-level data. Where flow-net procedures were not feasible, $K$ was estimated by averaging the $K$ values in adjacent areas. Aquifer-test data indicate that the hydraulic conductivity of the Coconino aquifer ranges from 8 to $40 \mathrm{ft} / \mathrm{d}$ and that it may vary by a factor of 2 or more in a few miles. In the area about $5 \mathrm{mi}$ south of Holbrook, however, the flow-net analysis indicates that the hydraulic conductivity may be as much as $80 \mathrm{ft} / \mathrm{d}$.

\section{Storage Coefficient}

For the places in which the water in the Coconino aquifer is confined in the northern and eastern parts of the area, storage coefficients were calculated using data from short-term aquifer tests, and the values range from 0.00013 to 0.0014 . Where aquifer-test data were not available, storage coefficients were assumed to be the average of those for a typical confined aquifer. The storage coefficient for a typical confined aquifer may be estimated by multiplying the thickness of the aquifer, in feet, by $10^{-6} \mathrm{ft}^{-1}$ (Lohman, 1972, p. 53). The storage coefficients calculated from aquifer-test data closely approximate the estimated values for a typical confined aquifer. Near Joseph City, the calculated values range from 0.00014 to 0.0014 and average about 0.0009. Although the minimum and maximum values differ by an order of magnitude, the average value is similar to the estimated 0.0007, which is the typical value for the confined aquifer at this location. Near Snowflake and Hay Hollow, aquifer-test data indicate that the 
average storage-coefficient values are 0.0004 and 0.0002 , respectively; the typical values range from 0.0004 to 0.00045 .

Where water in the Coconino aquifer is unconfined, storage-coefficient values could not be determined from the available field data but were estimated from laboratory determinations of specific yield. Samples of the Coconino Sandstone collected near Holbrook and Joseph City have a specific yield of 0.20 to 0.26 (Akers, 1964); however, the specific-yield values of the disturbed samples probably are larger than values obtained in the field, and the actual storagecoefficient values probably range from 0.1 to 0.2 . For this study, the average value was assumed to be 0.15 .

\section{WATER BUDGET}

The water budget for an area is the algebraic sum of all the inflow and outflow components. Under steady-state or equilibrium conditions, inflow equals outflow and no change occurs in the volume of water in storage. Under transient or nonequilibrium conditions, inflow and outflow are not in balance, and the difference is made up by a change in storage. This balance expresses a water budget, which, within the scope of this report, may be stated as

where

$$
Q_{\text {in }}-Q_{\text {out }}= \pm \Delta S,
$$

$$
\begin{aligned}
Q_{\text {in }}= & \text { the amount of inflow to the aquifer, } \\
& \text { in acre-feet per year; } \\
Q_{\text {out }}= & \text { the amount of outflow from the aquifer, } \\
& \text { in acre-feet per year; and } \\
\pm \Delta S= & \text { change in ground-water storage, in } \\
& \text { acre-feet per year. }
\end{aligned}
$$

In southern Navajo County water enters the Coconino aquifer by infiltration of precipitation that falls on the land surface, infiltration 
of storm runoff that collects in stream channels, and underflow from the adjacent areas on the east and west. Water is discharged from the aquifer by underflow across the north boundary, spring flow, streamflow, evapotranspiration, and pumping and flowing wells.

Although sufficient data were not available to make a detailed inventory of the water in each phase of the water budget, data were available to make a preliminary evaluation of the main factors that affect the ground-water supply and to compute a tentative water budget for the Coconino aquifer in 1960, which is assumed to be an equilibrium period. The data include records of precipitation, streamflow, pumpage, and water levels.

\section{Inflow}

Inflow to the Coconino aquifer is derived mainly from infiltration of the precipitation that falls on the land surface and from runoff of precipitation and snowmelt that collects in stream channels. In addition, underflow across the east and west boundaries of the study area accounts for a large amount of the water that moves through the aquifer, and vertical leakage from the confining bed may add a considerable amount of water to the aquifer in parts of the area. It is assumed that ground-water withdrawals were balanced by vertical leakage from the confining bed prior to extensive development.

Infiltration of precipitation and streamflow.--Infiltration from precipitation probably occurs in the spring, when the soil is saturated by melting snow for periods of several weeks or months. The main area of infiltration is near the Mogollon Rim, where precipitation is as much as 30 in. per year.

Inflow to the Coconino aquifer was estimated by flow-net analysis. Underflow was computed using eq 1 at selected cross sections where the hydraulic gradient, saturated thickness, and hydraulic 
conductivity were reasonably well defined. Inflow was assumed to equal the increased amount of underflow between two successive cross sections. For example, 3,590 acre-ft/yr of underflow moves through cross-section $A-A^{\prime}$ (fig. 2, table 1). The underflow originates in the area bounded by the ground-water divide near the Mogollon Rim, cross-section $A-A^{\prime}$, and flow lines. The underflow at cross-section $A-A^{\prime}$ is maintained by the infiltration of precipitation from an area of about $40 \mathrm{mi}^{2}$. The average inflow is estimated to be $90 \mathrm{acre}-\mathrm{ft} / \mathrm{mi}^{2} / \mathrm{yr}$; however, similar computations near Heber, Standard, and Pinetop indicate that the average inflow in most places near the Mogollon Rim may be as much as $120 \mathrm{acre}-\mathrm{ft} / \mathrm{mi}^{2} / \mathrm{yr}$. The computed increase in underflow between cross-sections $A-A^{\prime}$ and $B-B^{\prime}$ is about 2,480 acre-ft/yr (table 1). As determined from aquifer-test data, the hydraulic-conductivity values at cross-sections $A^{-} A^{\prime}$ and $B-B^{\prime}$ are about 12 and $23 \mathrm{ft} / \mathrm{d}$, respectively (table 1). The average hydraulic gradient, width of cross section, and average saturated thickness at cross-sections $A-A^{\prime}$ and $B-B^{\prime}$ were obtained from figures 2 and 3 . Infiltration probably occurs in only 33 of the $69 \mathrm{mi}^{2}$ in the flow-net area; the rest of the area is covered by the siltstone beds of the Moenkopi Formation, which impede infiltration. The increase of 2,480 acre- $\mathrm{ft} / \mathrm{yr}$ in the $33-\mathrm{mi}^{2}$ area indicates an average infiltration rate of about 75 acre-ft/mi2/yr.

In the southern part of the area the amount of inflow from infiltration of precipitation and streamflow is estimated to be 35,400 acre-ft/yr; the estimate is based on the sum of the calculated underflow values between each pair of flow lines (fig. 4). The flow-net analysis indicates that the average annual inflow derived from precipitation is probably negligible in the northern and central parts of the area, where the normal annual precipitation is not more than 14 in. (University of Arizona, 1965a, 1965b). The zero line of equal infiltration in figure 4 corresponds to the boundary between the confined and unconfined parts of the aquifer in the eastern part of the area and was arbitrarily extended westward from Snowflake through the middle of 
Table 1.--Results of flow-net analysis for area south of Snowflake

[The computed values are not meant to imply an accuracy to the number of significant figures shown]

\begin{tabular}{|c|c|c|c|c|c|c|}
\hline \multirow{2}{*}{$\begin{array}{l}\text { Cross section } \\
\text { (See figure } 2 \\
\text { for location) }\end{array}$} & \multirow{2}{*}{$\begin{array}{l}\text { Hydraulic } \\
\text { conductivity } \\
\text { (feet per } \\
\text { day) }\end{array}$} & \multirow{2}{*}{$\begin{array}{l}\text { Hydraulic } \\
\text { gradient } \\
\text { (foot per } \\
\text { foot) }\end{array}$} & \multirow{2}{*}{$\begin{array}{c}\text { Saturated } \\
\text { thickness } \\
\text { (feet) }\end{array}$} & \multirow{2}{*}{$\begin{array}{l}\text { Width of } \\
\text { cross } \\
\text { section } \\
\text { (feet) }\end{array}$} & \multicolumn{2}{|c|}{$\begin{array}{c}\text { Discharge through } \\
\text { cross section }\end{array}$} \\
\hline & & & & & $\begin{array}{l}\text { Cubic feet } \\
\text { per day }\end{array}$ & $\begin{array}{l}\text { Acre-feet } \\
\text { per year }\end{array}$ \\
\hline$A-A^{\prime}$ & 12 & 0.00476 & 250 & 30,000 & 428,400 & 3,590 \\
\hline$B-B^{\prime}$ & 23 & .00333 & 430 & 22,000 & 724,500 & 6,070 \\
\hline $\begin{array}{l}\text { Increase in } \\
\text { underflow } \\
\text { between } \\
\text { cross sections }\end{array}$ & & & & & 296,000 & 2,480 \\
\hline
\end{tabular}


T. $13 \mathrm{~N}$. Precipitation in the northern and central parts is sporadic and normally is the result of summer thunderstorms or light snowfall. Most of the precipitation probably is absorbed by the soil and is lost through evaporation, transpiration, or surface runoff.

Streamflow data are available only for Chevelon, Clear, and Silver Creeks and the Little Colorado River. The data indicate that about 175 acre-ft/mi/yr of streamflow is lost along Chevelon Creek ( T. M. Davey, written commun., 1974); similar losses occur along Clear Creek, but most of the losses are in reaches outside the study area. A large part of the streamflow probably is lost to evaporation. Chevelon Creek has many deep pools, which are more than $1 \mathrm{mi}$ long and a few hundred feet wide. Part of the water stored in the pools during periods of flow is lost to evaporation; however, part of the water infiltrates downward to the Coconino aquifer. The amount of infiltration in the $30-\mathrm{mi}$ reach downstream from Wildcat Canyon is estimated to be about 80 acre-ft/mi/yr or about 2,400 acre-ft/yr (fig. 4).

Another potential source of inflow to the aquifer is infiltration at Dry Lake-a closed basin that is fed by Phoenix Park Wash (fig. 4). Inflow to the aquifer from Dry Lake is assumed to be about 1,000 acre-ft/yr. On the basis of runoff values for Chevelon Creek and several other small drainage basins in the area, the average runoff into Dry Lake is estimated to be 3,500 acre-ft/yr; however, most of the water probably is lost to evaporation. Since 1961, Dry Lake has served as a disposal site for the effluent from the Snowflake Paper and Pulp Mill. After the effluent is deposited in the lake, the liquid evaporates, which leaves a fibrous residue that may act as a sealant on the bottom of the lake. Infiltration probably will decrease as the residue continues to collect on the lake bottom.

Infiltration of streamflow along the Little Colorado River between Silver Creek and the Puerco River may account for several hundred to a few thousand acre-feet per year of inflow to the aquifer (fig. 4). Streamflow data are insufficient to make a meaningful estimate 


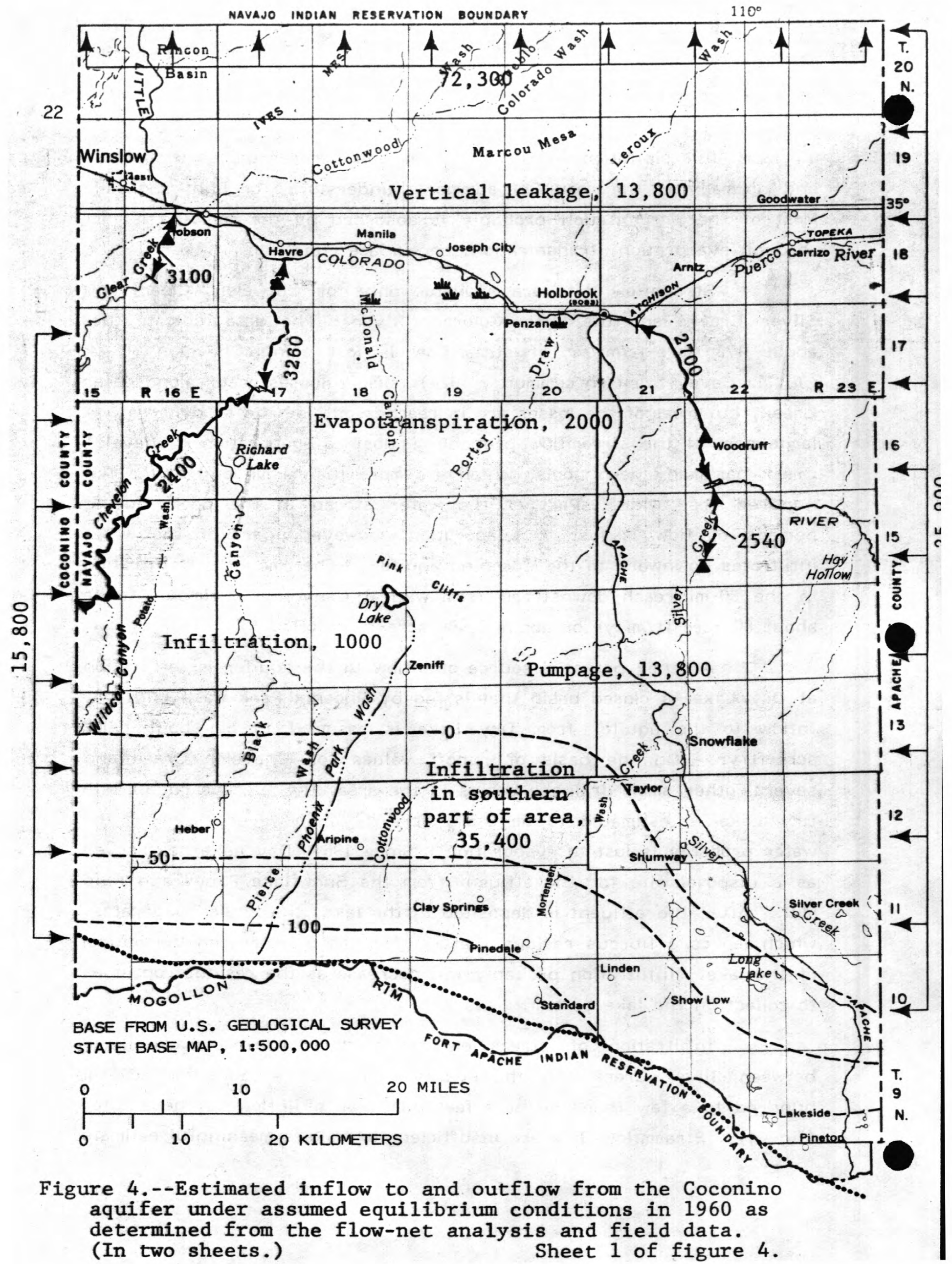




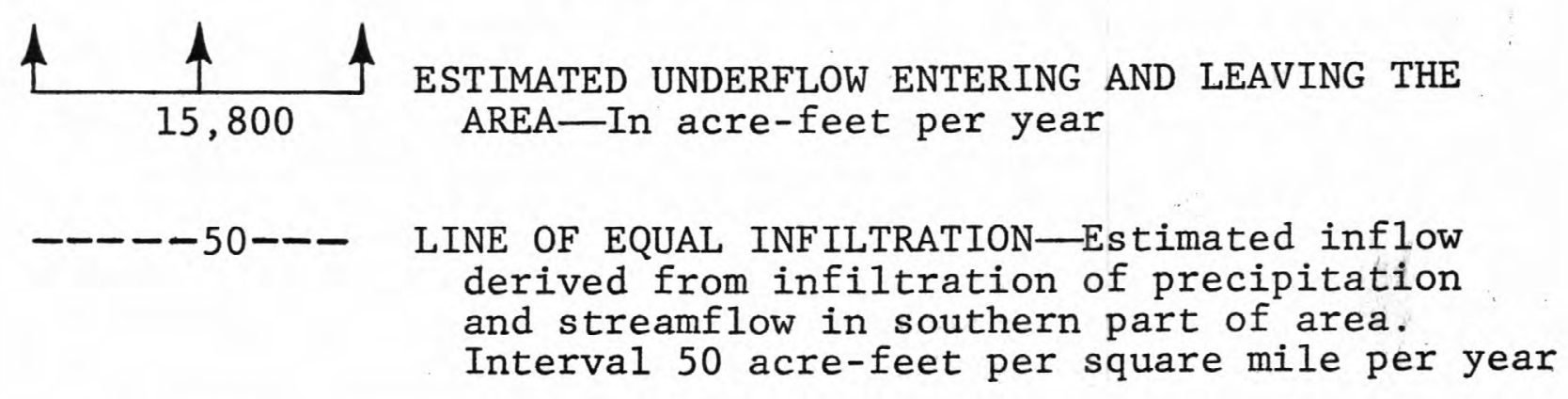

$\longleftarrow 2400 \longrightarrow$ ESTIMATED INFILTRATION ALONG STREAMS-In acrefeet per year

$\longrightarrow-3260 \rightarrow$ ESTIMATED OUTFLOW ALONG STREAMS - In acre-feet per year

GROUND-WATER DIVIDE-Shows approximate location. Forms south boundary of modeled area

wee MARSH

STREAMFLOW-GAGING STATION-Operated by U.S. Geologicàl Survey

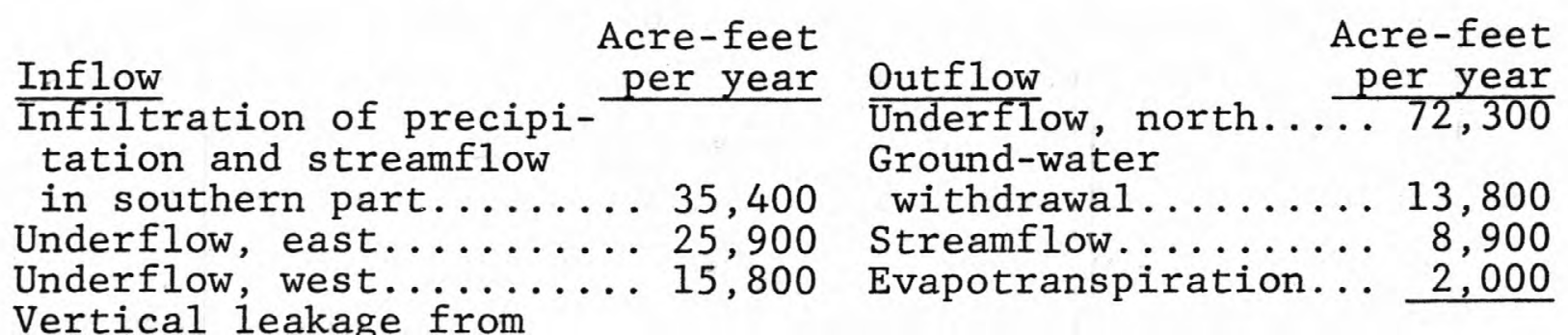

Vertical leakage from confining bed........13,800

Infiltration of stream-

flow along Little

Colorado River, Chevelon

Creek, and Dry Lake..... 6,100

Total.......... $\overline{\underline{97,000}}$

Total..... 97,000

Figure 4.--Estimated inflow to and outflow from the Coconino aquifer under assumed equilibrium conditions in 1960 as determined from the flow-net analysis and field data. (In two sheets.) Sheet 2 of figure 4. 
of the quantity of water that infiltrates to the aquifer; however, to balance the water budget, the amount of infiltration from the Little Colorado River and other undefined sources is estimated to be 2,700 acre-ft/yr (fig. 4).

Underflow.--Underflow across the east and west boundaries accounts for a substantial amount of ground-water inflow to the study area. Because the south boundary of the modeled area was established along the ground-water divide, underflow into the area across this boundary is zero. The widths of the flow sections on the east and west boundaries were varied depending on areal variations in saturated thickness, hydraulic gradient, hydraulic conductivity, and direction from which the underflow approaches the study area. The amount of underflow across the east boundary is estimated to be 25,900 acre-ft/yr; the amount across the west boundary is estimated to be 15,800 acre-ft/yr (fig. 4).

\section{Outflow}

In southern Navajo County ground water is discharged from the Coconino aquifer by underflow across the north boundary, spring flow, streamflow, evapotranspiration, and pumping and flowing wells. Underflow across the north boundary is the largest part of the outflow and probably has been nearly constant since before ground-water development began. Historically, the combined amount of outflow from springs, streams, and evapotranspiration was the second largest outflow component; in recent years, however, some of this outflow has been intercepted by wells. Because ground-water pumpage has increased substantially since about 1960, it now is the second largest component of the outflow.

An unknown amount of ground water is discharged from the Coconino aquifer into the alluvium along the flood plain of the Little Colorado River. In places the Moenkopi Formation, which confines 
ground water in the Coconino aquifer, is fractured or has been breeched or entirely stripped away by erosion, and the Coconino aquifer is hydraulically connected to the overlying alluvium. Data from wells near Joseph City and Winslow indicate that the potentiometric surface in the Coconino aquifer is nearly coincident with that in the alluvium. In some places water in the Coconino aquifer is discharged to the alluvium, and in other places water in the alluvium is recharged to the Coconino aquifer. Therefore, for purposes of this study, outflow from the Coconino aquifer to the alluvium and inflow to the aquifer from the alluvium are assumed to be in balance.

Underflow.--Underflow leaves the study area only along the north boundary. The magnitude of the flow was estimated using cross-sectional area, hydraulic gradient, and hydraulic conductivity of the aquifer (eq 1). The cross-sectional area of the aquifer at the north boundary is the product of the distance between the east and west boundaries, which is about $272,000 \mathrm{ft}$, and the saturated thickness of the aquifer, which ranges from less than $600 \mathrm{ft}$ to about $850 \mathrm{ft}$ (fig. 3). The hydraulic gradient ranges from 0.0025 to $0.0030 \mathrm{ft} / \mathrm{ft}$; the hydraulic conductivity along the north boundary ranges from about $8 \mathrm{ft} / \mathrm{d}$ in the east to about $16 \mathrm{ft} / \mathrm{d}$ in the west. The computed underflow is about 72,300 acre-ft/yr (fig. 4).

Streamflow and springs.--The base flow of Chevelon Creek, Clear Creek, the Little Colorado River, and the lower reaches of Silver Creek is maintained by ground-water outflow from the Coconino aquifer. Streamflow data, spring-flow measurements, and seepage investigations were used to determine the locations and amounts of ground-water outflow.

The ground-water outflow into Chevelon Creek was estimated on the basis of streamflow measurements made at the gaging station near Havre (fig. 4). The measurements indicate that the base flow is about $4.5 \mathrm{ft}^{3} / \mathrm{s}$ or 3,260 acre- $\mathrm{ft} / \mathrm{yr}$. 
The ground-water outflow into Clear Creek is estimated to be 3,100 acre-ft/yr (fig. 4). Streamflow data from the gaging station on Clear Creek near Winslow could not be used to estimate the base flow because of an ungaged diversion, leakage through Clear Creek Dam, and several springs and seeps downstream from the gaging station. However, measurements of inflow to the Little Colorado River at the mouth of Clear Creek range from 4.0 to $4.5 \mathrm{ft}^{3} / \mathrm{s}$ (table 2) and average about $4.3 \mathrm{ft}^{3} / \mathrm{s}$ or about 3,100 acre-ft/yr.

The ground-water outflow into Silver Creek in the reach between Snowflake and the Little Colorado River is estimated to be 2,540 acre-ft/yr (fig. 4). The estimate is based on discharge measurements made in February 1954 and May 1974, which indicate a net gain of about $3.5 \mathrm{ft}^{3} / \mathrm{s}$ (table 2 ).

In 1960 the ground-water outflow from the Coconino aquifer to streams was about 8,900 acre-ft (fig. 4), and, on the basis of available data, no long-term change has taken place. After the outflow becomes streamflow, some is diverted for irrigation at Woodruff, Joseph City, and Winslow, and the rest is lost by infiltration to the alluvium along the Little Colorado River; none crosses the north boundary of the area.

In 1946 the ground-water outflow from the aquifer to springs near the Little Colorado River near Holbrook and Joseph City was estimated to be 600 acre-ft (Babcock and Snyder, 1947, table 1). Most of the water moved upward through fractures in the Moenkopi Formation and was discharged to springs and seeps in the marshes on the south side of the river (fig. 4); however, the spring flow probably had been reduced considerably prior to 1946. In the early 1930's several wells that flowed at the land surface were drilled near the marshes. The wells probably intercepted flow that previously was discharged by the springs and seeps. By 1972, all the flow of the springs and seeps was being intercepted by pumping and flowing wells, and it is assumed that all the flow of the springs and seeps was being intercepted prior to 1960 . 
Table 2.--Discharge measurements of base flow at selected sites

\begin{tabular}{l|c|c}
\hline Measurement site & Date & $\begin{array}{c}\text { Discharge } \\
\text { (cubic feet per second) }\end{array}$ \\
\hline Clear Creek at mouth & February 10,1954 & $\underline{1 /} 4.4$ \\
October 10,1955 & May 16, 1974 & $\underline{1} 4.4$ \\
Silver Creek at mouth & February 11, 1954 & $\underline{1} 3.4$ \\
& May 15, 1974 & $\underline{1} 3.5$ \\
\hline
\end{tabular}

1/ Net gain; discharge was compiled from two or more measurements. 
In 1946 the ground-water outflow from the Coconino aquifer to streams and springs was about 9,500 acre-ft. By 1960, the outflow had been reduced to about 8,900 acre-ft, and it is assumed that the flow has remained constant.

Evapotranspiration.--In general, evapotranspiration losses from ground water in the Coconino aquifer probably are negligible. The depth to water in most of the area is more than $100 \mathrm{ft}$ below the land surface, and plants probably obtain their water from soil moisture rather than from ground water in storage. Near the Little Colorado River, however, a substantial amount of ground water is lost to the atmosphere by evapotranspiration. The marshes near Joseph City and Holbrook contain dense growths of vegetation that obtain their water from the aquifer.

The areal distribution of the marshes and the density of the vegetation were compared and estimated using aerial photographs taken in 1936 and 1971 and data from a field reconnaissance made in July 1973. In 1936 the marshes covered about 800 acres, and the plantcover density was 80 to 100 percent. Maximum water use is estimated to be 5 acre-ft/acre of dense growth (Anderson, 1976); therefore, for 1936, the potential evaporation loss from the 800 acres of marshland is estimated to be 4,000 acre-ft.

The aerial photographs taken in 1971 and the field reconnaissance made in July 1973 indicate that the marshes have changed considerably since 1936. The aerial photographs show that the plantcover density has decreased and in 1971 ranged from sparse to about 70 percent. Nearly a third of the marshland had virtually dried up by the time the field reconnaissance was made in 1973; the ground was dry in places where local residents reported that it was wet and boggy 10 to 20 years before. The information indicates that the evapotranspiration loss has decreased considerably. The evapotranspiration loss for 1971 is estimated to be 1,600 acre-ft-a decrease of 2,400 acre-ft since 1936 . The evapotranspiration loss for 1960 is not known but is estimated to be 
2,000 acre-ft (fig. 4). The decrease in potential evapotranspiration losses can be attributed to the lowering of the potentiometric surface owing to the increase in ground-water withdrawals.

Ground-water withdrawals.--About 367,000 acre-ft of water was withdrawn from the Coconino aquifer in southern Navajo County from 1960 to 1972 (fig. 5). Of the 38,400 acre-ft of water withdrawn from the aquifer in 1972, about 60 percent was for irrigation; 35 percent for industry; and 5 percent for municipal, domestic, and livestock supplies.

The increase in ground-water development was gradual prior to 1960. The first large-scale development was the drilling of a series of flowing wells near the Little Colorado River between Holbrook and Joseph City in the early 1930's. The wells were drilled to supplement the base flow of the Little Colorado River, which was diverted for irrigation. In 1946 about 4,300 acre-ft of water was withdrawn in the Holbrook-Joseph City area-3,700 acre-ft from the flowing wells and 600 acre-ft from pumped wells (Babcock and Snyder, 1947). On the basis of the drilling dates of wells that were in production in 1972, groundwater withdrawals from pumped and flowing wells are estimated to be less than 10,000 acre-ft/yr prior to 1951. Ground-water withdrawals increased to about 13,800 acre-ft in 1960 and to about 27,000 acre-ft in 1963, mainly owing to withdrawals by the Snowflake Paper and Pulp Mill near Snowflake and the Cholla Power Plant near Joseph City. Additional agricultural, industrial, and municipal demands increased withdrawals from about 27,000 acre-ft in 1963 to 38,400 acre-ft in 1972 (Mann, 1976, p. 32).

The amount of water discharged by the flowing wells in the Holbrook-Joseph City area was estimated to be 2,200 acre-ft in 1960 and less than 300 acre-ft in 1972. The decrease in discharge by flowing wells from 3,700 acre-ft in 1946 to 300 acre-ft in 1972 is attributed to an increase in withdrawals by nearby pumping wells for industrial and agricultural uses and the resultant decrease in artesian head. 


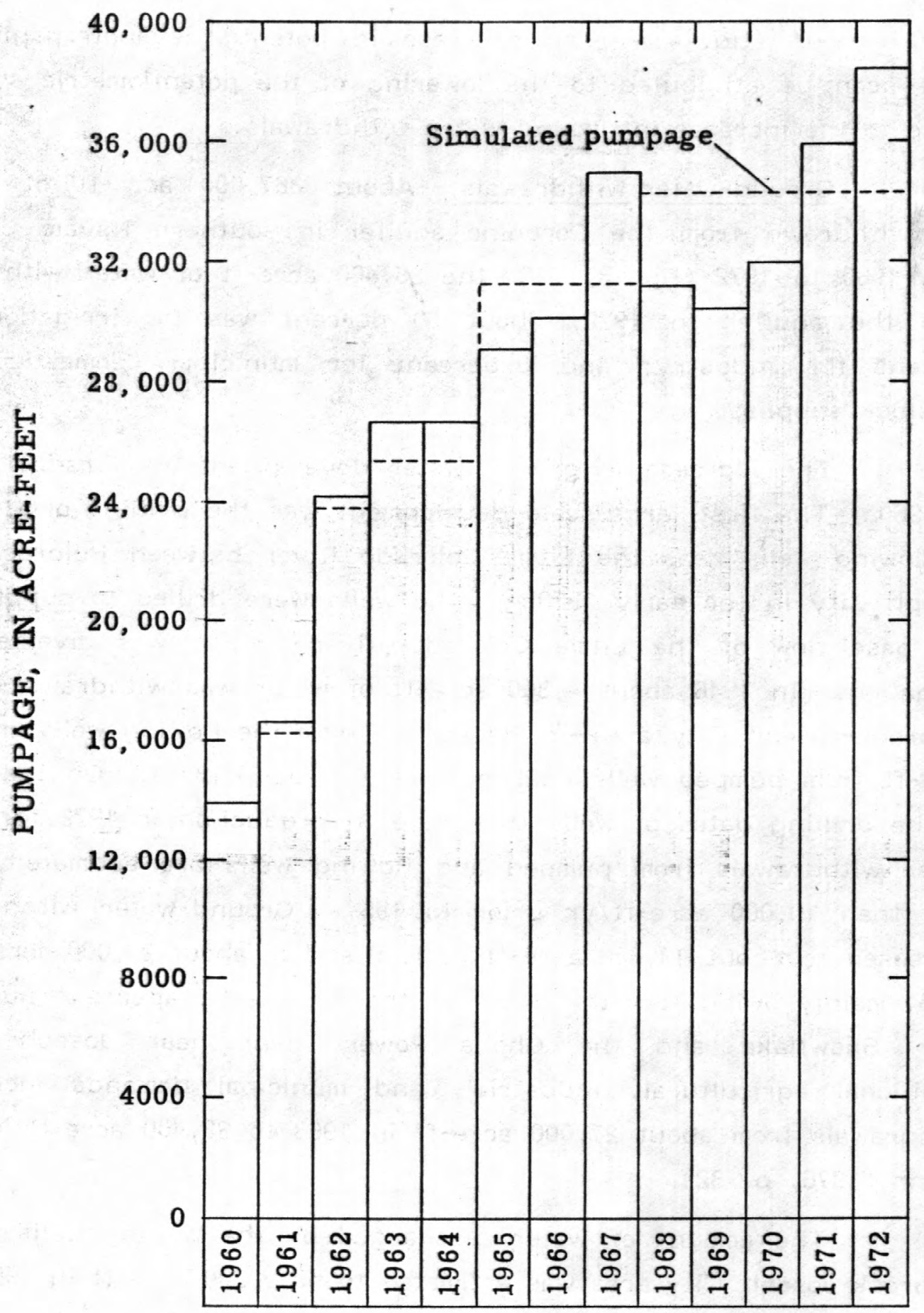

Figure 5.--Estimated ground-water pumpage from the Coconino aquifer, 1960-72. 


\section{Changes in Ground-Water Storage}

In general, long-term changes in ground-water storage in the Coconino aquifer are minimal and were assumed to be negligible in the 1960 water budget. Water-level measurements indicate that no progressive decline has occurred in most of the study area and that the water that has been withdrawn from the aquifer has been replenished by inflow, except locally.

In 1960 about 13,800 acre-ft of ground water was withdrawn from the Coconino aquifer, and the annual withdrawals were less prior to 1960. From 1960 to 1972, however, small cones of depression formed near the few major pumping centers. In 1972 the depth to water in several wells near Taylor was 30 to $50 \mathrm{ft}$ more than the depth measured in about 1960. During the same period, the water levels declined from 10 to $30 \mathrm{ft}$ in most wells near Snowflake and Shumway; declines of less than 1 to $20 \mathrm{ft}$ were measured near Joseph City, Holbrook, and Hay Hollow.

\section{MATHEMATICAL MODEL OF THE COCONINO AQUIFER}

A mathematical model was developed to approximate the flow quantities and the areal distribution of water levels in the Coconino aquifer. The computer program used to simulate ground-water flow in the aquifer was developed by Pinder (1970) and modified by Trescott (1973). Additional modifications that include the ability to simulate areal infiltration were made by $P$. C. Trescott and G. F. Pinder (written commun., 1974). The program will adequately simulate all the aquifer conditions in southern Navajo County.

Quantitative model-input data include two types-fixed data and variable data. The fixed input data were defined at the beginning of the analysis and generally were not changed. The fixed input data include the geometric description of the aquifer, such as the dimensions of the model, node size, boundaries of the model area, and the base of 
the aquifer. The location of constant-head and constant-flux boundaries, pumpage for each time period, and measured water levels also are considered fixed data.

Variable input data include parameters that are subject to modification when attempting to simulate mathematically ground-water flow in the aquifer. Variable data include aquifer hydraulic conductivity, storage coefficient, and water-budget parameters. The parameters were varied within the limits defined by the flow-net analysis and the field data.

The nodal arrangement of the model consists of 3,313 elements or nodes; each node represents $1 \mathrm{mi}^{2}$ (fig. 6). In most of the area the density of the hydraulic characteristics and water-budget data was not sufficient to justify a grid size of less than $1 \mathrm{mi}^{2}$ per node. A $1-\mathrm{mi}^{2}$ grid was believed to be the best compromise between the available data and the desired results.

Boundaries used in the model were of two types-constant head and constant flux. A constant-head boundary can act as a source to simulate inflow or as a sink to simulate outflow from the aquifer. Constant-head boundaries were established along the ground-water divide at the south boundary of the area, along the Little Colorado River between its confluence with Silver Creek and the Puerco River, and along the north boundary of the area (fig. 7). The constant-head boundaries along the ground-water divide and the Little Colorado River served as a source of inflow, and the constant-head boundary along the north boundary served as a sink. A constant-flux boundary was established along the east and west boundaries of the area. The value of the constant flux at each node was based on the underflow values determined from the flow-net analysis.

Other natural flow losses and gains in the aquifer include water discharged by springs, water lost through evapotranspiration, inflow to the aquifer from nonuniform areal infiltration, and infiltration 
from Dry Lake and Chevelon Creek. The natural losses from the aquifer are simulated in the model by pumping wells.

Simulation of ground-water flow in the aquifer was accomplished in two phases. The first phase was the steady-state simulation in which the-predevelopment (1960) flow conditions were modeled. The object of the first phase was to simulate ground-water flow in the aquifer using known and estimated values for aquifer characteristics and water-budget parameters. As a calibration procedure, the water levels generated by the model were compared with those measured in 1960. After the water levels were simulated in the model within the accuracy of the data and the inflow and outflow quantities were adjusted, the second phase or transient simulation was developed. The object of the second phase was to match water-level changes generated by the model with measured water-level changes during a comparable period of time. When large differences were found, the variable data were modified within the limits defined by the flow-net analysis and the field data so that the model changes better approximated the measured changes.

\section{Steady-State Simulation}

Under steady-state conditions, the aquifer is assumed to be in a state of equilibrium, and changes in ground-water storage are negligible. Therefore, the amount of water entering the system is balanced by the amount of water leaving the system. The Coconino aquifer was in approximate equilibrium in 1960. Prior to 1960, pumpage was less than 13,800 acre-ft/yr, and data indicate no appreciable water-level decline.

The steady-state analysis is useful because the response of the model could be reduced to a simple stress-and-effect relation among inflow, outflow, hydraulic conductivity, saturated thickness, and hydraulic gradient. The steady-state analysis was used mainly to 


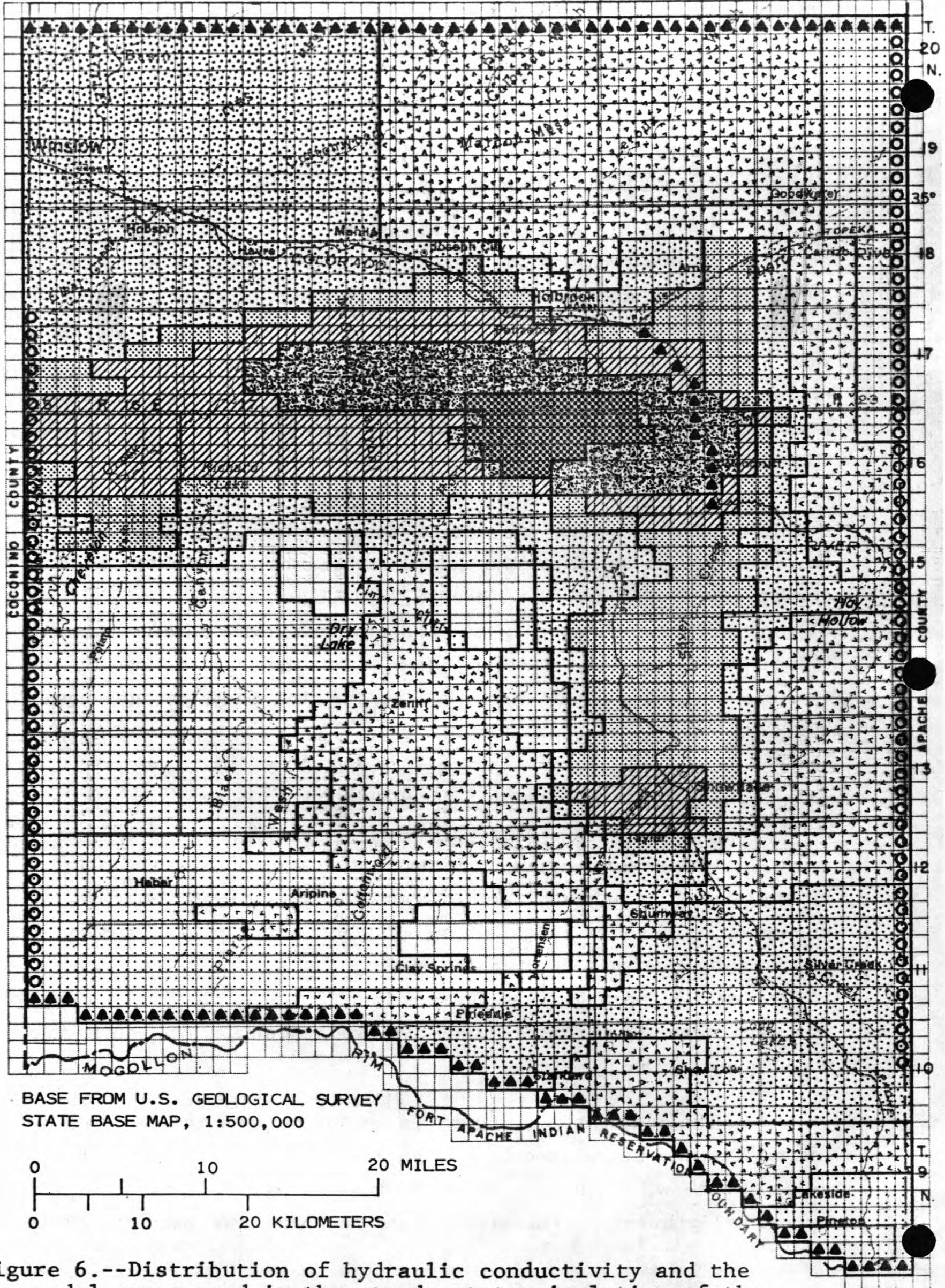

Figure 6.--Distribution of hydraulic conductivity and the nodal array used in the steady-state simulation. of the Coconino aquifer. (In two sheets.) 


\section{HYDRAULIC CONDUCTIVITY IN FEET PER DAY}

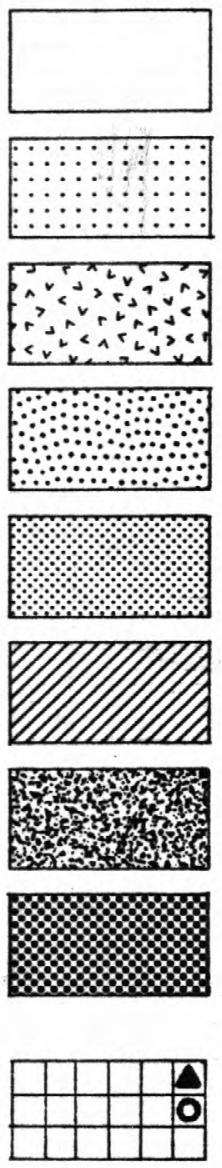

$2-4$

$5-8$

$9-12$

$13-16$

$17-20$

$21-30$

$31-50$

$51-80$

NODE-Each node represents 1 square mile in the model. The triangle is shown in nodes used to simulate a constant-head boundary. The circle is shown. in nodes used to simulate a constant-flux boundary

Figure 6.--Distribution of hydraulic conductivity and the nodal array used in the steady-state simulation of the Coconino aquifer. (In two sheets.) 


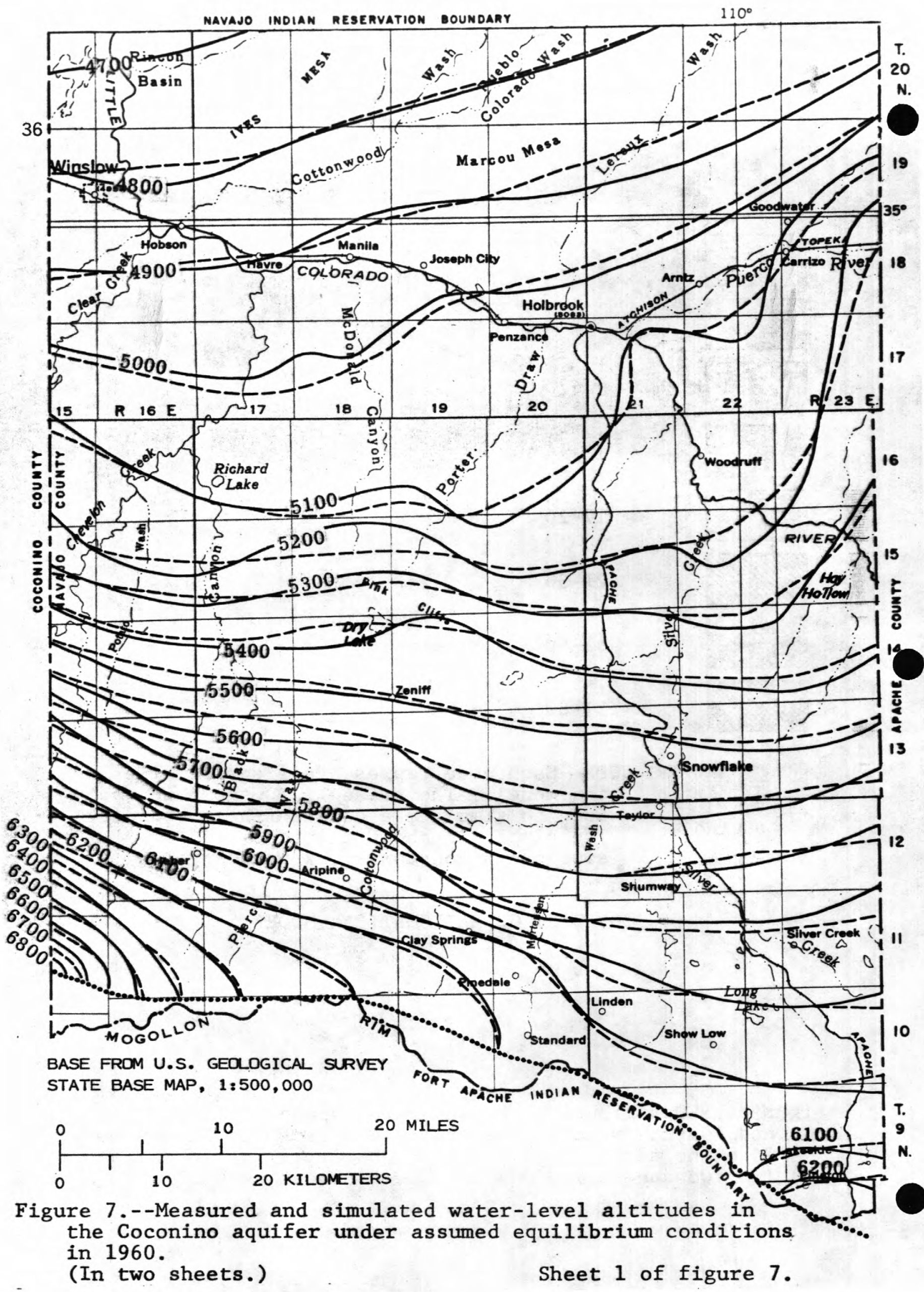




\section{- 5500- POTENTIOMETRIC CONTOUR-Shows approximate altitude at which water level would have stood in tightly cased well. Contour interval 100 feet. Datum is mean sea level}
- - 5500- - SIMULATED POTENTIOMETRIC CONTOUR-Shows water-level altitude simulated by the steady-state model. Contour interval 100 feet. Datum is mean sea level

GROUND-WATER DIVIDE-Shows approximate location. Forms south boundary of modeled area

Figure 7.--Measured and simulated water-level altitudes in the Coconino aquifer under assumed equilibrium conditions in 1960 .

(In two sheets.)

Sheet 2 of figure 7 . 
evaluate and modify the variable model-input data. In general, the water-budget and hydraulic-conductivity parameters were put in the model as estimated by the flow-net analysis; for the steady-state analysis, however, the data were modified within the accuracy limits established by the field data and the flow-net analysis. All the data used in the model are included in this report except for altitude of the top of the Coconino aquifer, which was obtained from the structurecontour map of the top of the Coconino Sandstone (Mann, 1976); the contours were modified slightly to include the Kaibab Limestone in places where it is saturated.

In general, the steady-state model was insensitive to changes in hydraulic conductivity of less than 10 percent. The steady-state analysis indicated that a percentage change in inflow or outflow values affected the hydraulic gradients and water levels considerably more than a similar change in hydraulic conductivity. To obtain a significant change in a large area, it was necessary to increase or decrease the hydraulic conductivity by 25 to 50 percent. The hydraulic-conductivity values that were required to obtain a reasonable match between the model-generated and measured water levels are shown in figure 6 . Because the model was insensitive to small changes in hydraulic conductivity, the values were averaged over large areas.

In general, the model-generated water-level values closely approximated the measured values (fig. 7). Although the generated values in a few nodes differed from the measured values by as much as $75 \mathrm{ft}$, the average difference per node was about $17 \mathrm{ft}$. The discrepancies between the model-generated and measured values are the result of inaccuracies in the variable input data and (or) possibly erroneous measured values. In the northern and southwestern parts of the area few wells tap the aquifer, and the measured values for most of the wells are based on reported water levels.

The steady-state analysis indicates that about 105,600 acre-ft/yr of ground-water inflow and outflow was required to obtain a 
reasonable match between the model-generated water levels and the measured water levels (fig. 7). The final flow rates used in the model are shown on table 3 .

The water budget obtained by the flow-net analysis indicates that inflow and outflow were about 97,000 acre-ft/yr (fig. 4), and the steady-state analysis indicates about 105,600 acre-ft/yr (table 3). Although some of the water-budget values estimated by the two methods are different, the annual inflow and outflow values differ by only 8,600 acre-ft or about 9 percent.

\section{Transient Simulation}

The transient model was developed by adding simulated storage and pumpage to the steady-state model and including time as an added dimension. The initial transient simulation included all the input parameters and boundary conditions used in the steady-state model. In addition, the head values generated during the steady-state simulation were substituted for the measured head values; thus, changes in head owing to ground-water withdrawals could be analyzed independently from the changes resulting from inaccuracies in the water-budget and hydraulic-characteristics data.

In most of the area ground-water withdrawals from the aquifer are not large enough to cause measurable water-level declines, and the storage-coefficient and specific-yield parameters could not be verified. Near Snowflake, Shumway, Holbrook, and Joseph City, however, ground-water withdrawals have been large enough to cause significant local water-level declines. Because of the close approximation of the confined storage coefficient to the typical value (see section entitled "Storage Coefficient") and the lack of areally extensive data, the typical values were used in the simulation (fig. 8). On the basis of the specific-yield data, the unconfined value was assumed to average about 0.15 . To determine the accuracy of the estimated 
Table 3.--Water budget used in steady-state simulation

$\underline{\text { Acre-feet per year }}$

INFLOW:

Infiltration of precipitation:

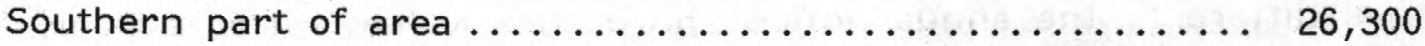

Simulated by constant-head boundary

along the ground-water divide................. 17,800

Infiltration of streamflow:

Chevelon Creek ............................ 2,400

Dry Lake ............................... 1,000

Simulated by constant-head boundary

along Little Colorado River between

Silver Creek and Puerco River .................. 4,800

Underflow:

East boundary ........................... 25,900

West boundary .......................... 15,800

Vertical leakage from confining bed ............. 11,600

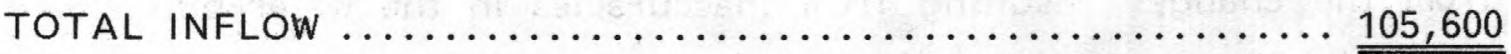

\section{OUTFLOW:}

Underflow across north boundary

simulated by constant-head boundary .............. 82,600

Ground-water withdrawal ...................... 12,600

Streamflow:

Chevelon Creek ......................... 3,260

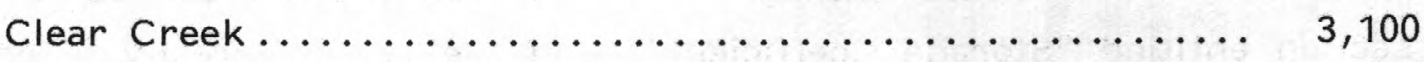

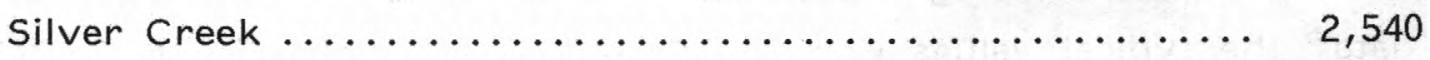

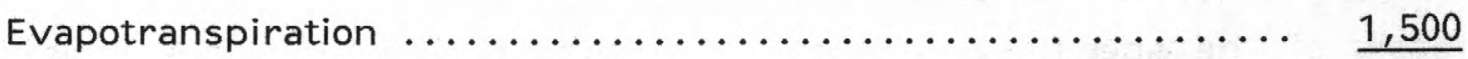

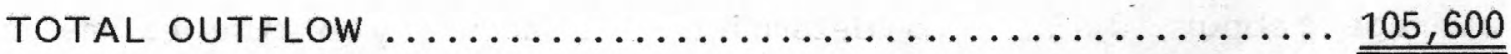


storage-coefficient values, pumpage values were incorporated into the transient model, and the model-generated water-level declines were compared with the measured declines on an areal basis and at individual points on a temporal basis.

In southern Navajo County pumpage increased from about 13,800 acre-ft in 1960 to 38,400 acre-ft in 1972 (fig. 5). Six time periods were used to simulate the pumpage with time. Although the actual pumping of individual wells is started and stopped at different times, all pumping simulated in the model starts and stops simultaneously. In addition, simulated pumpage in a particular node is the sum of the pumpage from all wells in the $1-\mathrm{mi}^{2}$ nodal area and is treated as if it were being withdrawn from one centrally located well. The pumping rate for each node remains constant throughout each time period; the rate is changed, however, from node to node and from time period to time period. By generalizing the pumpage, data-preparation and computer time were greatly reduced with little or no effect on the accuracy of the final results. The pumpage by township for 1960-72 is shown in figure 8.

The initial transient simulations indicated that the modelgenerated water-level declines generally were 5 to $30 \mathrm{ft}$ more than the measured declines, particularly near Taylor, Snowflake, Shumway, Joseph City, and Holbrook. The simulated decline of about $13 \mathrm{ft}$ for a

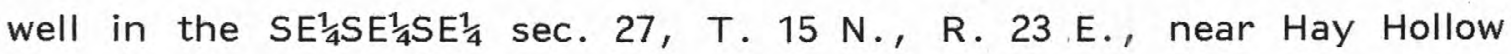
was comparatively close to the measured decline for 1965-72, but was slightly more than the measured decline for 1960-64 (fig. 9). To obtain a closer approximation of the measured declines near Taylor, Snowflake, Shumway, Joseph City, and Holbrook, vertical leakage from the confining bed was incorporated in the model. Vertical leakage was incorporated in the model because the declines could not be simulated by adjusting the confined storage coefficient within the limits established by the field data. 
NAVAJO INDIAN RESERVATION BOUNDARY

42

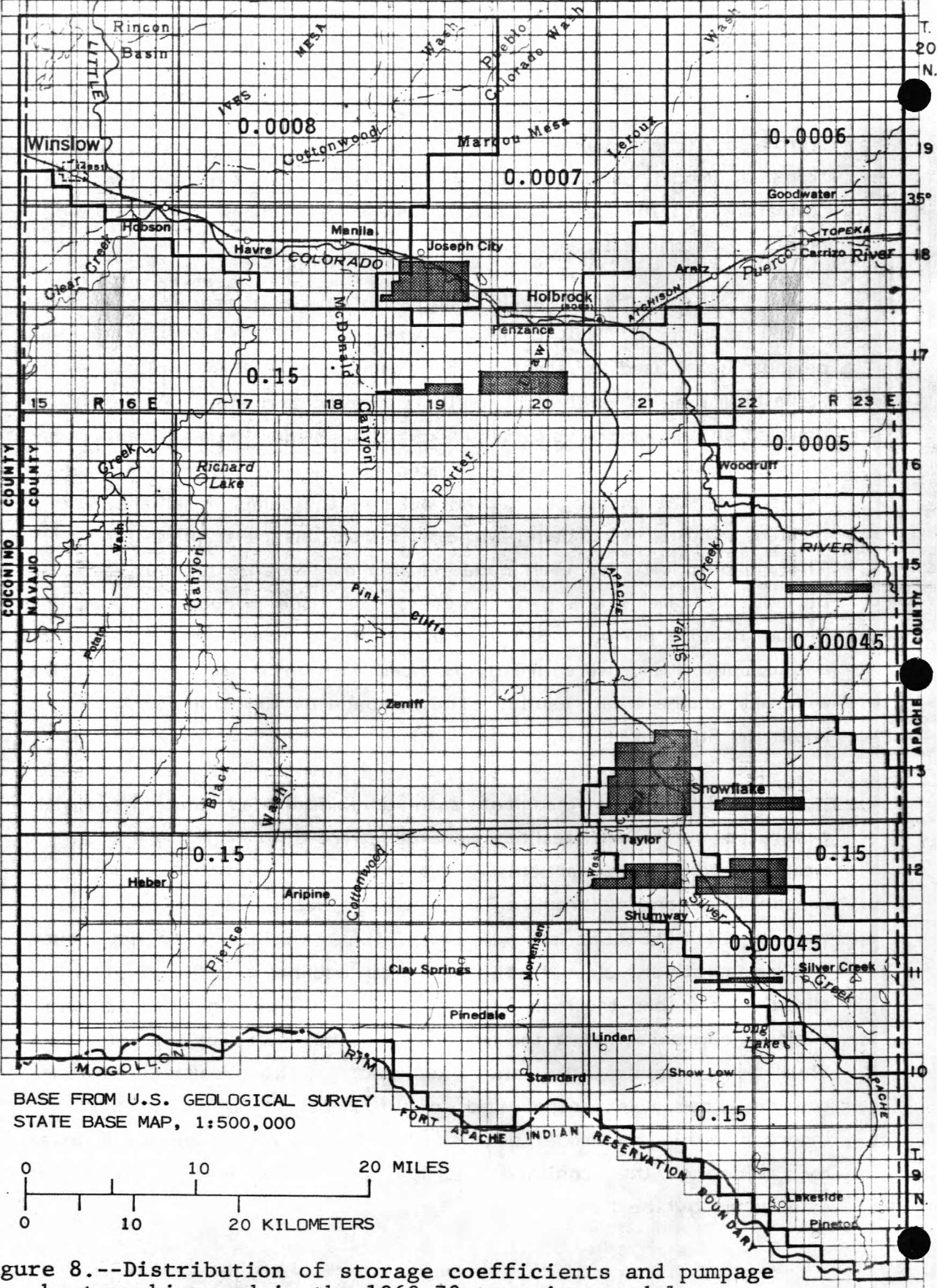

Figure 8.--Distribution of storage coefficients and pumpage

by township used in the 1960-72 transient model.

(In two sheets.)

Sheet 1 of figure 8 . 
0.0005

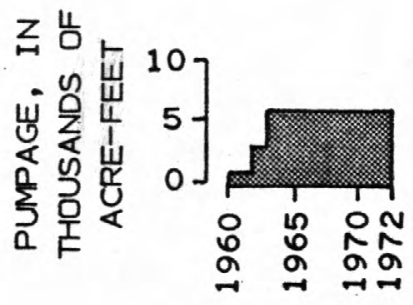

STORAGE $\cdot$ COEFFICIENT

PUMPAGE BY TOWNSHIP, 1960-72

Figure 8.--Distribution of storage coefficients and pumpage by township used in the 1960-72 transient model. (In two sheets.) Sheet 2 of figure 8 . 

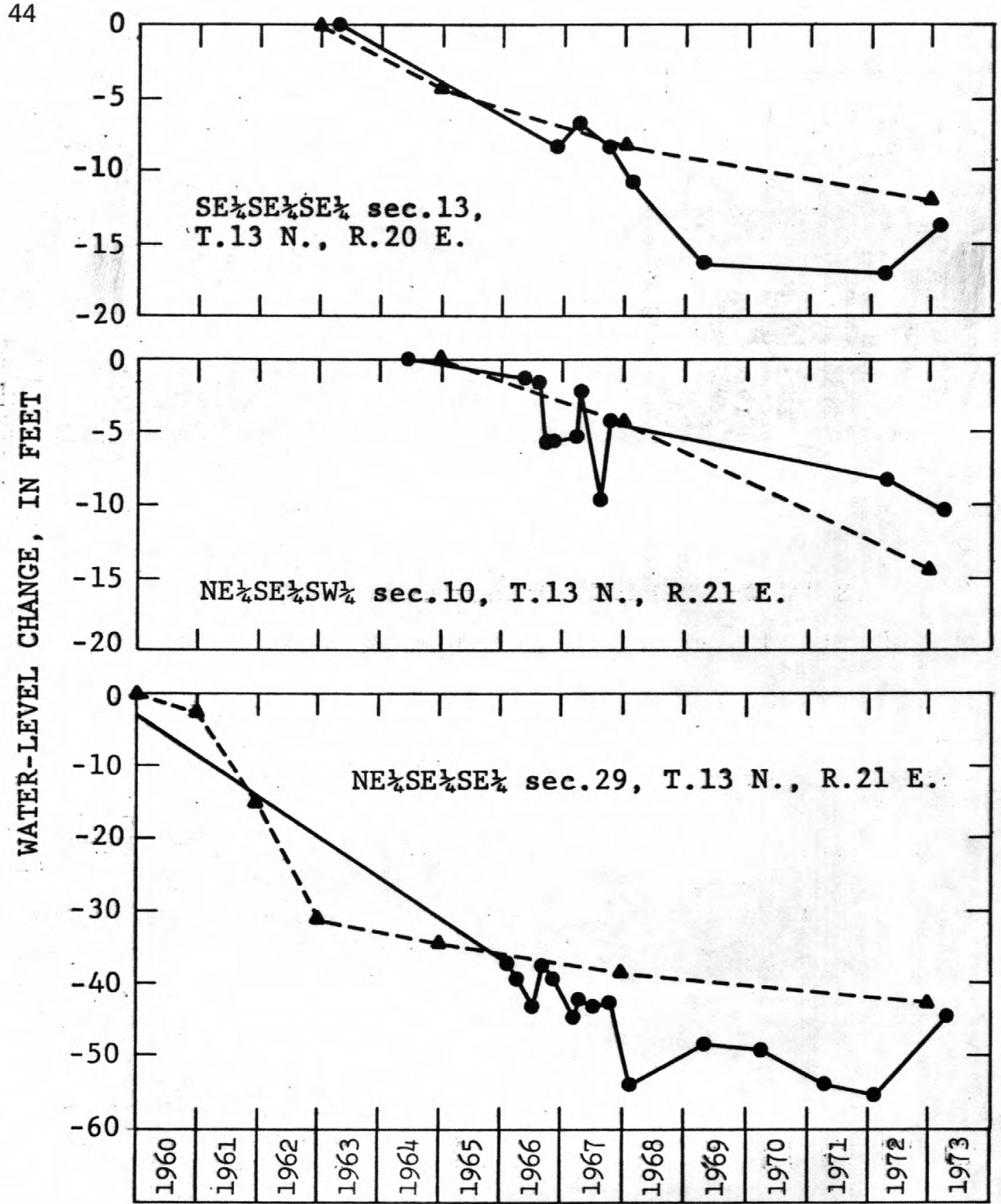

E X P L A N A T I O N

- Measured water-level decline

- Simulated water-level decline

Figure 9.--Measured and simulated water-level changes in selected wells, 1960-73.

(In two sheets.) Sheet 1 of figure 9. 


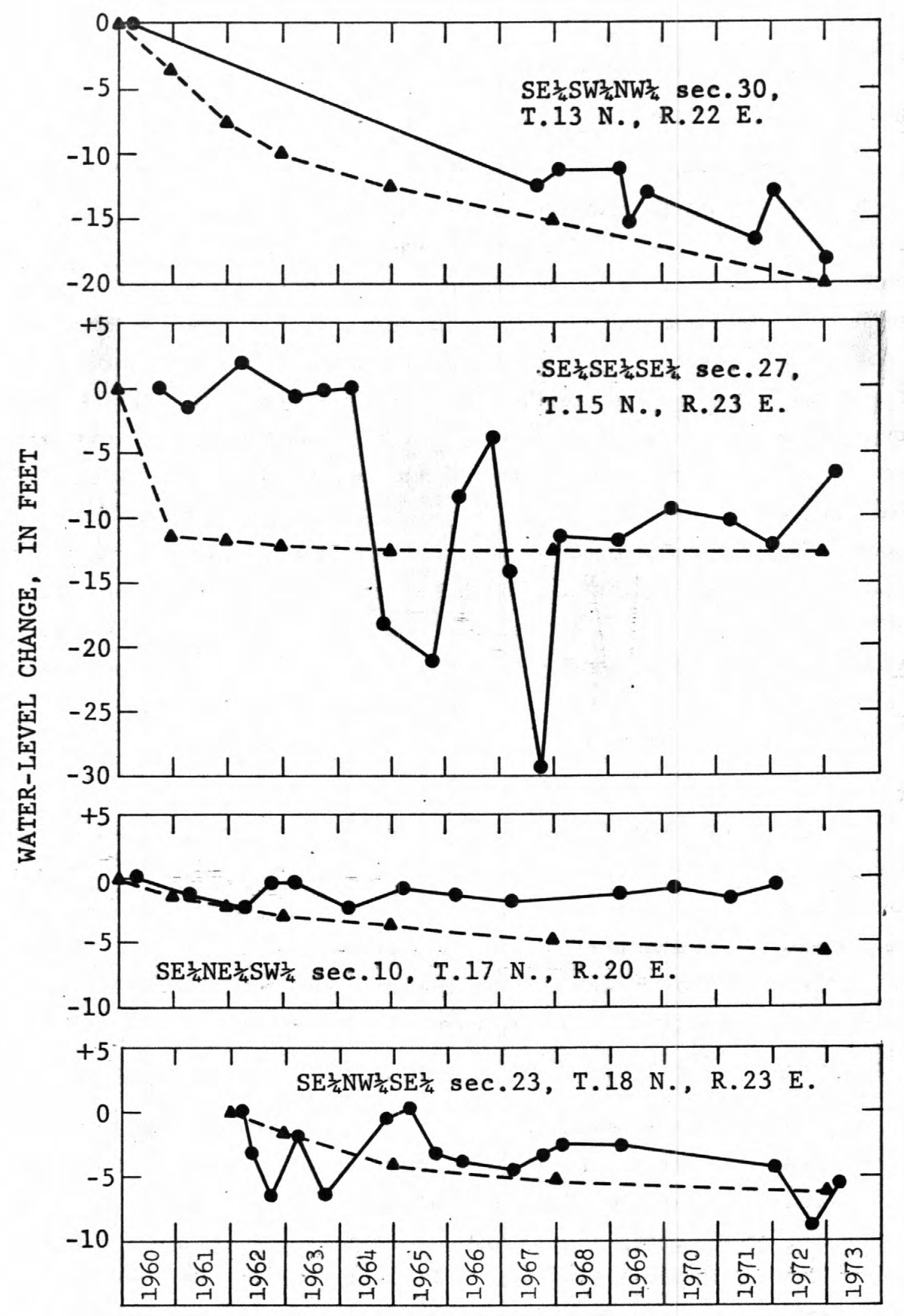

Figure 9.--Measured and simulated water-level changes in selected wells, 1960-73.

(In two sheets.) Sheet 2 of figure 9. 
The amount of vertical leakage is controlled by the thickness, vertical hydraulic conductivity, specific storage, and head on the confining bed. The confining bed was assumed to have a uniform thickness of $100 \mathrm{ft}$, which approximates the thickness of the Moenkopi Formation near Snowflake and along the Little Colorado River near Holbrook and Joseph City. Initially, the vertical hydraulic conductivity of the confining bed was estimated to be between 0.01 and $0.1 \mathrm{ft} / \mathrm{d}$; however, a final value of $0.004 \mathrm{ft} / \mathrm{d}$ was chosen because of the close approximation of the model-generated and measured water-level declines after this correction was made. The specific storage is estimated to be about 0.0005 , and the head on the confining bed is assumed to be the same as the head in the aquifer before any significant ground-water withdrawals. After vertical leakage was incorporated in the model, hydrographs of model-generated and measured water-level declines in selected observation wells were compared, and, in general, the simulated declines were within a few feet of the measured declines (fig. 9).

In the Snowflake-Shumway area the general pattern of measured and model-generated water-level declines could not be as closely approximated as the measured and model-generated declines in the selected observation wells. In general, the model-generated declines were 10 to $15 \mathrm{ft}$ less than the measured declines in the center of the area and from 5 to $15 \mathrm{ft}$ more than the measured declines along the perimeter of the area (fig. 10).

The differences between the model-generated and measured declines can be attributed to one or more of the following conditions: (1) inaccuracies in the hydraulic-conductivity and (or) saturatedthickness input data; (2) areal variations in vertical hydraulic conductivity of the confining bed, which was assumed to be uniform for simulation; (3) questionable accuracy of the measured declines owing to many reported original static water levels; (4) many water-level measurements in wells that are open to thin water-bearing sandstone 
R. $20 \mathrm{E}$.

R. $21 \mathrm{E}$.

R. $22 \mathrm{E}$.

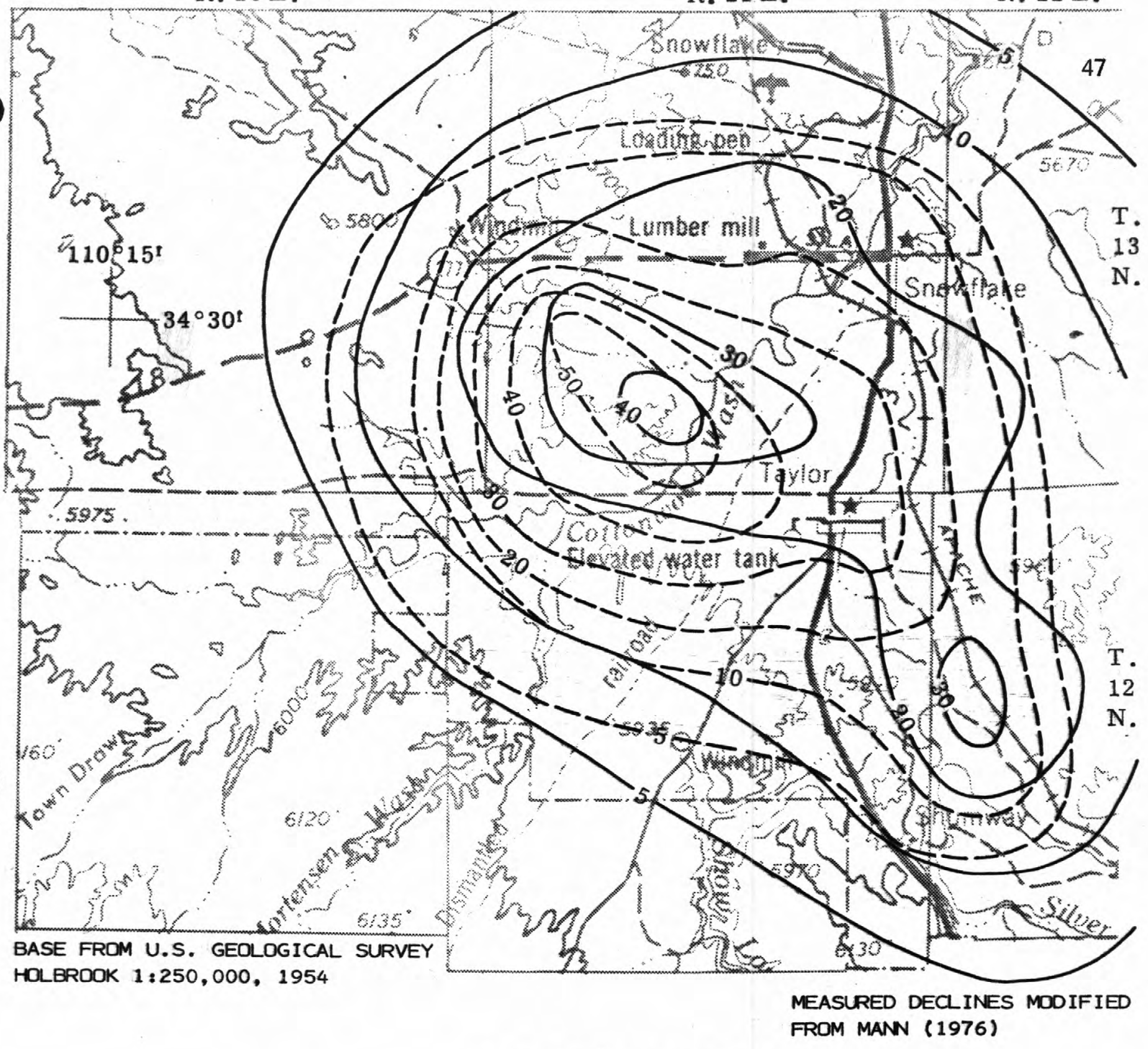

E X P L A N A T I O N

- - 10- - APPROXIMATE LINE OF EQUAL MEASURED WATER-

LEVEL DECLINE, SPRING 1951 TO SPRING

1973-Intervais 5 and 10 feet

10

LINE OF EQUAL SIMULATED WATER-LEVEL DECLINE,

1960-72-Intervals 5 and 10 feet

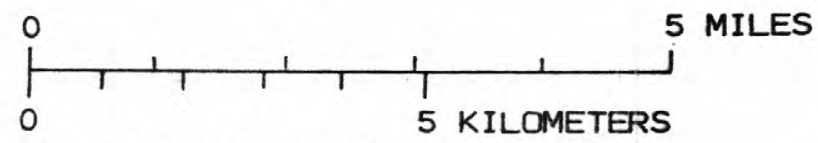

CONTOUR INTERVAL 200 FEET

Figure 10.--Measured and simulated water-level declines near Snowflake, Taylor, and Shumway. 
beds that overlie the aquifer and, thereby, represent a composite head that may be a few feet higher or lower than the head in the aquifer, depending on the difference in head between the two zones; and (5) local changes in inflow from the infiltration of precipitation and streamflow that differ greatly from average conditions.

In general, the simulated declines near Holbrook and Joseph City were greater than the measured declines. In these areas, waterlevel data indicate that no appreciable decline has occurred; however, the simulated declines generally were 5 to $10 \mathrm{ft}$. The model-simulated water-level changes for 1960-72 for the entire study area are shown in figure 11. The differences between the simulated and measured declines probably result from an unknown amount of inflow to the aquifer from the alluvium along the Little Colorado River.

The simulated decline near Holbrook and Joseph City is centered in the Cholla Power Plant well field. The decline in the node used to simulate pumpage from the well field is slightly less than $19 \mathrm{ft}$ compared with the measured decline of about $17 \mathrm{ft}$ in 1970 (Guyton and Associates, 1971).

The transient analysis indicates that about 192,000 acre-ft of water was derived from ground-water storage from 1960 to 1972 (table 4). Minor changes in flow quantities, such as those for underflow at the north boundary and inflow along the Little Colorado River between Silver Creek and the Puerco River, occurred in 1960-72. The water budget for the transient simulation represents an approximation of the annual quantities of inflow and outflow for 1960-72. The transient model represents average conditions, and the flow quantities can depart significantly from the average conditions during any one year.

\section{Limitations and Use of the Model}

The closeness of fit of the model to real-world conditions and to changes therein depends on the accuracy and adequacy of the field 
Table 4.--Average annual water budget for the transient simulation, 1960-72

$\frac{\text { Acre-feet }}{\text { Average } \quad \underline{\text { Range }}}$

INFLOW:

Infiltration of precipitation:

Southern part of area ............ 26, 300

Simulated by constant-head boundary along the ground-water divide........ 17,800

Infiltration of streamflow:

Chevelon Creek ................... 2,400

Dry Lake ..................... 1,000

Simulated by constant-head boundary along Little Colorado River between

Silver Creek and Puerco River ......... 5,000

4,800 to 5,300

Underflow:

East boundary ................. 25,900

West boundary ................... 15,800

Vertical leakage from confining bed....... 12,100 4,300 to 15,700

TOTAL INFLOW ............... 106,300

\section{OUTFLOW:}

Underflow across north boundary simulated by constant-head boundary ...... 82,000

Ground-water withdrawals ............ 28,900

Streamflow:

Chevelon Creek ................ 3,260

Clear Creek .................... 3, 100

Silver Creek ..................... 2,540

Evapotranspiration ............. 1,500

TOTAL OUTFLOW ................. 121,100

WATER DERIVED FROM STORAGE

(INFLOW MINUS OUTFLOW) ............. $-14,800$ 


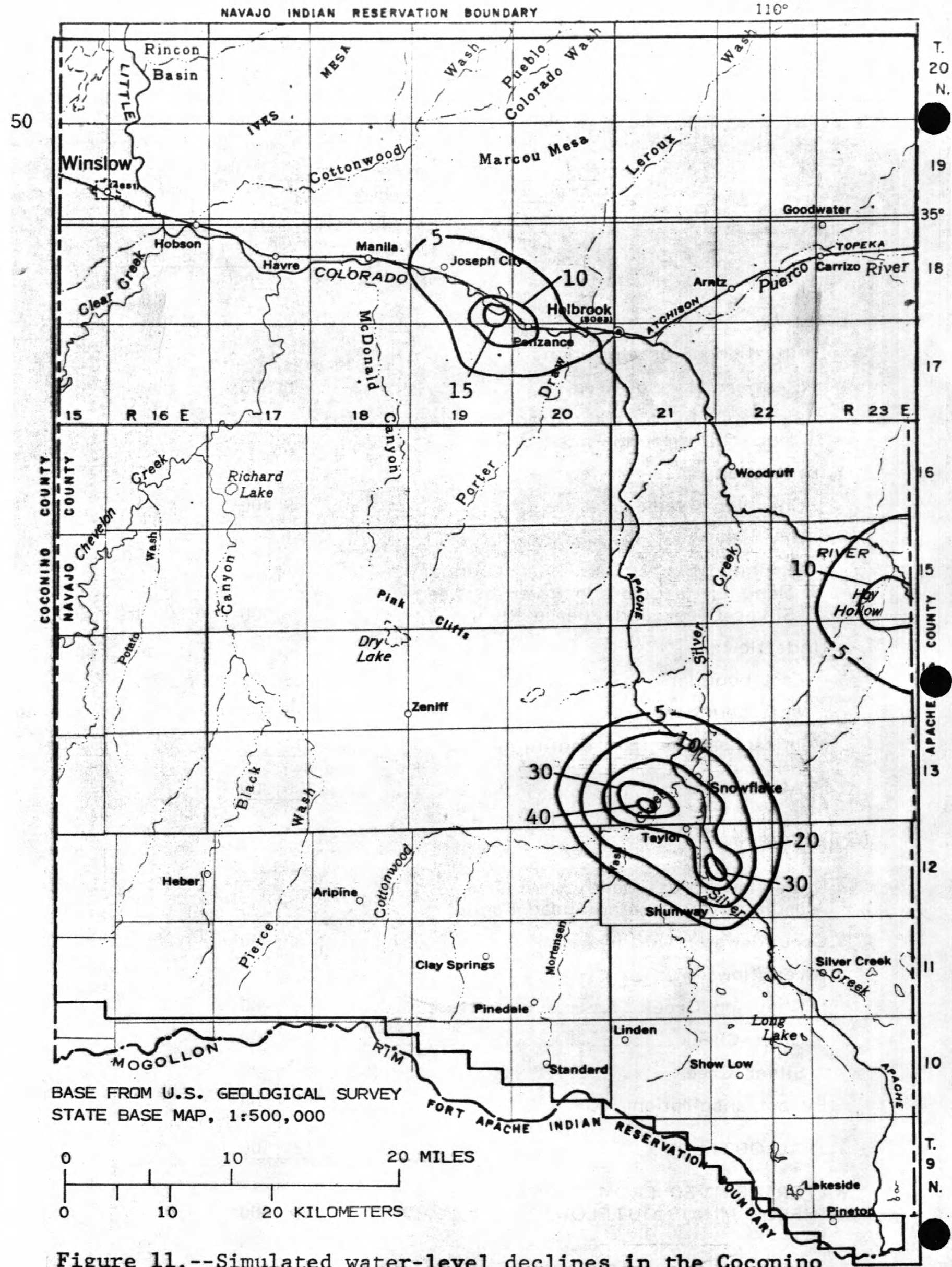

Figure 11.--Simulated water-level declines in the Coconino aquifer, 1960-72.

(In two sheets.) $\quad$ Sheet 1 of figure 11. 
10 - APPROXIMATE LINE OF EQUAL SIMULATED WATERLEVEL DECLINE-Intervals 5 and 10 feet

BOUNDARY OF MATHEMATICAL MODEL

Figure 11.--Simulated water-level declines in the Coconino aquifer, 1960-72. (In two sheets.) 
data and on the assumptions made in the development of the model. The mathematical model is based on the following assumptions:

(1) All flow within the aquifer is two dimensional-no vertical flow components.

(2) Inflow and outflow are uniformly distributed areally within the given boundaries and temporally for a given period.

(3) The aquifer is isotropic and homogeneous within the boundaries indicated for different hydraulicconductivity and storage-coefficient values.

The transient model was developed to provide a management tool for estimating the effects of present and future ground-water withdrawals. Data for many of the parameters necessary to develop the model are not precisely known or are not available, and the model is a simplified generalization of the actual ground-water system. Generalizations incorporated in the model were made to simplify many of the complexities of the actual ground-water system. The generalizations do not degrade the usefulness of the model but keep the analysis within the limits of accuracy established by the basic data.

The most significant generalization incorporated in the model is the simulation of the aquifer in two dimensions; the aquifer is three dimensional. The hydraulic conductivity and storage coefficient change vertically and laterally owing to changes in grain size, degree of cementation, and fracturing. The assumption of uniform vertical hydraulic conductivity and storage coefficient may be seriously in error if the vertical changes are locally significant. Vertical changes in aquifer characteristics will result in corresponding changes in the rate of water-level decline.

Another generalization, which could limit the use of the model, is the method of simulating inflow and natural outflow from the aquifer. Inflow and natural outflow values were simulated without considering seasonal and annual variations. The generalizations were 
necessary because most of the inflow data were derived from the flow-net analysis and were assumed to represent average conditions. Natural outflow data were estimated on the basis of periodic streamflow measurements and potential evapotranspiration rates derived by empirical methods. The generalizations should not limit the use of the model in estimating the long-range impact of ground-water development.

The constant-head boundaries used to simulate inflow and outflow will limit the use of the model if the effects of future ground-water withdrawals intercept the boundaries. For example, the constant-head boundaries that were used to simulate outflow will react as inflow boundaries if the effects of withdrawal from future pumping intercept the boundaries. The solution is to replace the constant-head boundaries with constant-flux boundaries or to extend the boundaries of the model if and when the problem arises.

The model is sufficiently accurate to provide an estimate of the changes in the ground-water system in response to future development. To retain its usefulness as a management tool, however, the model must be improved and updated as additional information becomes available. An annual water-level measurement network should be established to monitor variations at particular points, and pumpage data should be updated periodically.

The greatest data needs for improvement of the model are for data that define the water budget and hydraulic characteristics of the aquifer. Most of the data in the present model are based on the flow-net analysis and estimated pumpage, which may be in error. As more wells are drilled into the Coconino aquifer, additional data that define the water budget and hydraulic characteristics of the aquifer will become available, and these data can be incorporated easily into the model. 


\section{SUMMARY}

The principal source of water in southern Navajo County is the Coconino aquifer. The Coconino aquifer consists of the Coconino Sandstone, the uppermost part of the underlying Supai Formation, and the overlying Kaibab Limestone. The Coconino Sandstone is the main water-bearing unit in the aquifer and yields from about 500 to 2,000 $\mathrm{gal} / \mathrm{min}$ of water to wells in all but two structurally high areas-along the crest of the Holbrook anticline and northwest of Heber-where water is obtained from the siltstone, sandstone, and evaporite beds in the uppermost part of the Supai Formation. In the southern and central parts of the area, water is under unconfined conditions, and in the northern and eastern parts, water is under confined conditions and may rise as much as $500 \mathrm{ft}$ above the top of the aquifer.

In general, the movement of water in the Coconino aquifer is northward from the Mogollon Rim toward the Little Colorado River. Water is discharged as underflow across the north boundary and to wells, springs, and seeps along the Little Colorado River and its major tributaries. The downgradient movement of water from areas of inflow to areas of outflow is controlled by the saturated thickness, hydraulic conductivity, and storage coefficient of the aquifer.

The saturated thickness of the Coconino aquifer ranges from about $150 \mathrm{ft}$ near the Mogollon Rim to $850 \mathrm{ft}$ near Winslow. In general, the saturated thickness includes only the saturated sandstone and limestone beds. In most of the area, the underlying siltstone beds of the Supai are assumed to be impervious and to impede the downward movement of water. Because the sandstone and limestone beds are above the zone of saturation along the crest of the Holbrook anticline, as much as $350 \mathrm{ft}$ of fractured siltstone that locally is interbedded with halite, gypsum, and anhydrite is arbitrarily included in the saturated thickness. 
The hydraulic conductivity of the Coconino aquifer is not uniform, and varies vertically and laterally throughout the area. The lithologic characteristics and the degree of fracturing of the aquifer are the main factors that affect hydraulic conductivity. Aquifer-test data indicate that the hydraulic conductivity ranges from 8 to $40 \mathrm{ft} / \mathrm{d}$; however, the flow-net analysis indicates that the hydraulic conductivity may be as much as $80 \mathrm{ft} / \mathrm{d}$ in places.

Water in the Coconino aquifer occurs under confined and unconfined conditions. Where water in the aquifer is confined, aquifer-test data indicate that the storage coefficient ranges from 0.00013 to 0.0014 and closely approximates the typical value for a confined system. Where water in the aquifer is unconfined, the storage coefficient could not be determined from the available field data but probably ranges from 0.1 to 0.2 . For purposes of this study, the average value was assumed to be 0.15 .

Inflow to the Coconino aquifer is balanced by natural outflow and pumpage plus or minus changes in ground-water storage. Inflow to the aquifer is from infiltration of precipitation and streamflow and underflow across the east and west boundaries. Outflow from the aquifer includes underflow across the north boundary, spring flow, streamflow, evapotranspiration, and ground-water withdrawals.

In 1972 about 38,400 acre-ft of water was withdrawn from the aquifer compared with about 13,800 acre-ft in 1960. No appreciable water-level declines occurred prior to 1960; by 1972, however, several isolated cones of depression had formed near the major agricultural and industrial pumping centers. Although the water levels in several wells have declined as much as $50 \mathrm{ft}$, the decline generally ranges from 0 to $20 \mathrm{ft}$.

A mathematical model was developed to determine if the estimated hydraulic characteristics, inflow, and outflow would provide a 
reasonable simulation of the actual ground-water system. The model was developed using all the available geohydrologic data, and steady-state and transient analyses were made. The steady-state simulation provided an approximation of the hydraulic-conductivity values and the water-budget parameters. The hydraulic-conductivity values and water-budget parameters were modified using trial-and-error techniques until a reasonable match was obtained between the model-generated and the measured water levels. The steady-state model indicated that inflow and outflow values probably were about 105,600 acre-ft in 1960, which was assumed to be an equilibrium period.

The transient model was developed by adding simulated storage and pumpage to the steady-state model and including time as an added dimension. The confined storage coefficients were assumed to be equal to the coefficient for a typical confined aquifer; the unconfined storage coefficient probably ranges from 0.1 to 0.2 . The storage coefficients could not be used to calibrate the model. Using the coefficient for a typical confined aquifer and by varying the unconfined coefficient between 0.1 and 0.2 , the model-simulated water-level declines were greater than the measured declines. To obtain a reasonable approximation, vertical leakage from the Moenkopi Formation, which acts as a confining bed, was incorporated into the model. The model indicates that an average of about 14,800 acre-ft/yr was removed from ground-water storage in 1960-72, a negligible quantity in contrast to the large volume stored in the aquifer.

The model provides an approximation of the actual ground-water system and can be used to estimate the future response of the aquifer to changes in inflow and outflow rates. To retain its usefulness as a management tool, the model must be improved and updated periodically using current and reliable data. 


\section{REFERENCES CITED}

Akers, J. P., 1964, Geology and ground water in the central part of Apache County, Arizona: U.S. Geol. Survey Water-Supply Paper 1771, $107 \mathrm{p}$.

Anderson, T. W., 1976, Evapotranspiration losses from flood-plain areas in central Arizona: U.S. Geol. Survey Open-File Rept. 76-864, $91 \mathrm{p}$.

Babcock, H. M., 1948, Memorandum on ground-water supply of the Joseph City Irrigation District: U.S. Geol. Survey open-file rept., $9 \mathrm{p}$.

Babcock, H. M., and Snyder, C. T., 1947, Ground-water resources of the Holbrook area, Navajo County, Arizona, with a section on Quality of water, by J. D. Hem: U.S. Geol. Survey open-file rept., $27 \mathrm{p}$.

Guyton, W. F., and Associates, 1971, Report on ground-water conditions in the vicinity of Arizona Public Service Company's Cholla Plant near Joseph City, Arizona: William F. Guyton and Associates duplicated rept., $30 \mathrm{p}$.

Harrell, M. A., and Eckel, E. B., 1939, Ground-water resources of the Holbrook region, Arizona: U.S. Geol. Survey Water-Supply Paper 836-B, p. 19-105.

Johnson, P. W., 1962, Water in the Coconino Sandstone for the Snowflake-Hay Hollow area, Navajo County, Arizona: U.S. Geol. Survey Water-Supply Paper 1539-S, 46 p.

Lohman, S. W., 1972, Ground-water hydraulics: U.S. Geol. Survey Prof. Paper 708, $70 \mathrm{p}$.

Mann, L. J., 1976, Ground-water resources and water use in southern Navajo County, Arizona: Arizona Water Comm. Bull. 10, $106 \mathrm{p}$. 
Peirce, H. W., and Scurlock, J. R., 1972, Arizona well information: Arizona Bur. Mines Bull. 185, $195 \mathrm{p}$.

Pinder, G. F., 1970, A digital model for aquifer evaluation: U.S. Geol. Survey open-file rept., 44 p.

Scurlock, J. R., 1971, Geologic structure of northern Arizona-State of Arizona: Arizona Oil and Gas Conservation Comm. map.

Theis, C. V., Brown, R. H., and Meyer, R. R., 1963, Estimating the transmissibility of aquifers from the specific capacity of wells, in Methods of determining permeability, transmissibility, and drawdown, Ray Bentall, compiler: U.S. Geol. Survey Water-Supply Paper 1536-I, p. I331-I341.

Trescott, P. C., 1973, Iterative digital model for aquifer evaluation: U.S. Geol. Survey open-file rept., 63 p.

University of Arizona, 1965a, Normal annual precipitation-normal May-September precipitation-1931-1960, State of Arizona: Arizona Univ. map. 1965b, Normal annual precipitation-normal October-April precipitation-1931-1960, State of Arizona: Arizona Univ. map. 



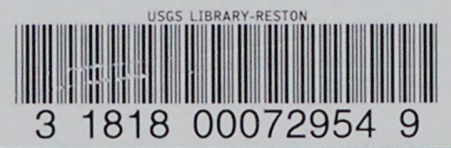

